University of Rhode Island

DigitalCommons@URI

Open Access Master's Theses

1979

\title{
Coastal Zone Management and the National Interest: \\ Massachusetts and Rhode Island
}

James T. Thomas

University of Rhode Island

Follow this and additional works at: https://digitalcommons.uri.edu/theses

\section{Recommended Citation}

Thomas, James T., "Coastal Zone Management and the National Interest: Massachusetts and Rhode Island" (1979). Open Access Master's Theses. Paper 610.

https://digitalcommons.uri.edu/theses/610

This Thesis is brought to you for free and open access by DigitalCommons@URI. It has been accepted for inclusion in Open Access Master's Theses by an authorized administrator of DigitalCommons@URI. For more information, please contact digitalcommons-group@uri.edu. 


\author{
COASTAL ZONE MANAGEMENT AND \\ THE NATIONAL INTEREST: \\ MASSACHUSETTS AND RHODE ISLAND
}

BY

JAMES ST。THOMAS

\begin{abstract}
A RESEARCH PROJECT SUBMITTED IN
PARTIAL FULFILLMENT OF THE REQUIREMENTS

FOR THE DEGREE OF MASTER OF

COMMUNTY PLANNING
\end{abstract}

UNIVERSITY OF RHODE ISLAND

1979 


\section{MASTER OF COMMUNITY PLANNING}

RESEARCH PROJECT

OF

JAMES ST。THOMAS

Approved:

Major Professor

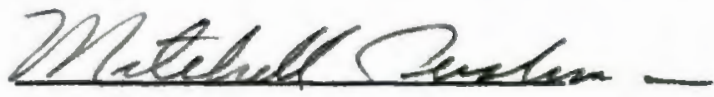
Mitchell Cushman

Director

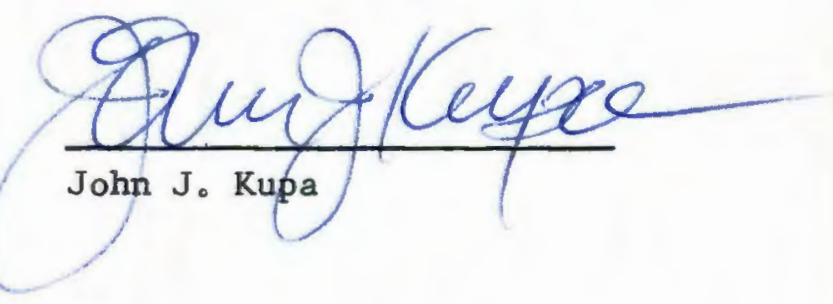


TABLE OF CONTENTS

ABSTRACT $\ldots \ldots \ldots \ldots \ldots \ldots \ldots \ldots \ldots \ldots \ldots \ldots \ldots \ldots \ldots \ldots \ldots \ldots \ldots \ldots \ldots \ldots \ldots \ldots \ldots \ldots \ldots \ldots \ldots \ldots$ i, ii

INTRODUCTION

CHAPTER 1 THE EVOLUTION OF THE NATIONAL INTEREST PROVISION: PROBLEMS OF INTERPRETATION

Comments of the petroleum industry on Interim Final Coastal Zone Management Program Development and Approval Regulations ............

Comments of the Edison Electric Institute on Interim Final Regulations on State Coastal Management Programs Development and Approval ...........

Judge Kelleher's interpretation of the national interest provision:

American Petroleum Institute V Robert $W_{0}$ Knecht .................

Chapter 1 Footnotes $\ldots \ldots \ldots \ldots \ldots \ldots \ldots \ldots \ldots \ldots \ldots \ldots \ldots \ldots \ldots \ldots \ldots \ldots \ldots \ldots \ldots$

CHAPTER II PROGRAM EVALUATIONS $\ldots \ldots \ldots \ldots \ldots \ldots \ldots \ldots \ldots \ldots \ldots \ldots \ldots \ldots \ldots \ldots \ldots \ldots \ldots 26$

Rhode Island and the national interest provision $\ldots \ldots \ldots \ldots \ldots \ldots \ldots \ldots \ldots$

Massachusetts and the national interest provision ................ 37

Composition of Massachusetts Energy Facility Siting Council _..... 44

Energy Facility Siting Council and the national interest ........ 45

Chapter II Footnotes .................................... 54

CHAPTER III PROGRAM RECOMMENDATIONS $\ldots \ldots \ldots \ldots \ldots \ldots \ldots \ldots \ldots \ldots \ldots \ldots \ldots \ldots \ldots \ldots . . \ldots$

Establishing Assessment Criteria ............................ 57

Recommendations: Massachusetts Coastal Zone Management Program ........ 60

Recommendations: Rhode Island Coastal Zone Management Program ......... 64

Area For Further Study: A Regional Approach to National Interest

Facility Siting ....................... 68

Chapter III Footnotes $\ldots \ldots \ldots \ldots \ldots \ldots \ldots \ldots \ldots \ldots \ldots \ldots \ldots \ldots \ldots \ldots \ldots \ldots \ldots \ldots$ 72

Appendix ............................................. 73

Personal Interviews ...................................... 76

Bibliography $\ldots \ldots \ldots \ldots \ldots \ldots \ldots \ldots \ldots \ldots \ldots \ldots \ldots \ldots \ldots \ldots \ldots \ldots \ldots \ldots \ldots \ldots \ldots \ldots \ldots \ldots \ldots, 7\rangle$ 


\section{RESEARCH PROJECT ABSTRACT}

The 1976 amendments to the Coastal Zone Management Act (CZMA) were primarily aimed at enabling the statute to better accommodate the demands placed on coastal resources by an increase in domestic energy exploration and production.

The national interest provision (Section 306(c)(8) confronts the problem of potential conflicts arising out of the pursuit of equally important coastal zone management goals as stated in the CZMA. The CZMA states that there is a national interest in the "effective management, beneficial use, protection and development of the Coastal Zone". Due to the increasing likelihood of more energy facility sitings in the coastal zone, Congress wanted to make sure that "adequate consideration" was given to energy facility siting proposals. The national interest provision and attendant federal regulations are designed to ensure that each federally approved coastal zone management program treats such proposals in a comprehensive fashion.

Congress' wording of the national interest provision is the cause of much controversy. "Adequate consideration" is subject to various interpretations by state and federal officials and private industry. Chapter I reviews the CZMA's legislative history, court proceedings, state and federal records and private industry comments to display the complexity involved in interpreting the national interest provision. Chapter II evaluates how well Massachusetts and Rhode Island coastal zone management programs comply with the national interest clause. Both states compliance procedures are subject to question as there have not been any specific cases involving the national interest to this date. Massachusetts and Rhode Island's programs are ambiguous 
with regard to how final decisions on national interest facility sitings are made.

Chapter III presents findings and conclusions with regard to Massachusetts and Rhode Island's compliance with the national interest provision. Program recommendations are made pursuant to the goals as stated by Congress in the CZMA. The major finding in both states is that there is a lack of adequate national interest assessment criteria. Decision makers presently review federal and private industry impact assessments, however, they have nothing to base their evaluations on. It is advocated here that a facility should be subject to national interest scrutiny whenever a NEPA assessment is required. After such designation, federally promulgated national interest assessment guidelines should be available for state and local decision makers. Such standards will unify each state's approach to national interest facility siting and ensure equal treatment of project proposals.

Specifically, Massachusetts should provide for better consideration of national interest facilities valued at less than five million dollars. Presently, the Energy Facility Siting Council is responsible for fulfilling the national interest provision, but is not legally bound to do so. Measures should be taken to depoliticize the national interest process in Massachusetts.

Rhode Island does not have an energy facility siting body and is in need of an adequate energy facility planning process. The Coastal Resources Management Council is the best mechanism available for implementing this planning process. Rhode Island also needs a stronger regulatory mechanism to ensure that the regional benefit clause of the CZMA is not ignored. Non-compliance with the regional benefit clause 
could undermine the effects of the national interest provision. An energy facility siting process similar to Massachusetts Energy Facility Siting Council would ensure such compliance.

Lastly, regional consideration of national interest proposals is advocated in an effort to improve upon the comprehensive approach now attempted in considering the national interest. 


\section{Introduction}

Historically, the national interest concept is grounded in the sixteenth and seventeenth centuries in the then modern states of Italy and England。Now antiquated, such terms as "The Will of the Prince" and dynastic interests" were gradually replaced with reference to the nation, which was in keeping with the rising tide of nationalism。

With the establishment of the Constitution, the national interest idea was seized upon and used extensively by American diplomats in asserting the righteousness of various national policies. Traditionally, the national interest in America has been thought of on an international scale. As a new nation which battled its way to its present supremacy, the United States had to conduct its international affairs from a "better thyself" or a national interest standpoint. By the end of World War II the U。S。 had established itself as the most formidable global power. However, as this supremacy emerged, the emphasis on the national interest in international politics began to decline.

Since the Vietnam War and the war on poverty, a new dimension has been added to the national interest concept. Internalization of national priorities, a common phenomenon after a war, was and is a major force in the 1970's. Isolationist sentiments, coupled with festering urban problems and a new environmental awareness, have resulted in the evolution of a new national interest. The domestic national interest is now existing alongside the traditional national interest as exercised in international politics. The United States has come to realize that the consequences of growth must be recognized and the needs of American citizens have to be considered from a holistic viewpoint. Federal, state and local governments, as well as private concerns, should learn to consider the national 
interest before embarking on a large scale project. We can no longer allow activities to be carried on in a vacuum. The "every man for himself" attitude in America must be changed if the nation's resources are to be managed properly for the benefit of existing and future generations. An outgrowth of this new concern with the management of the nation's resources was an increased awareness of the valuable nature of the coastal zone. Events in the late ' 60 's, such as the Santa Barbara oil spill, heightened this awareness. Legislation was passed which, among other things, aimed at preventing damage to estuaries, fishery resources, beaches, waters, air and submerged lands in the coastal zone. Indeed, provisions of the Clean Air Act and Federal Water Pollution Control Act are incorporated into any program under the Coastal Zone Management Act (CZMA) as air and water quality requisites. ${ }^{2}$

During the attempt at passage of the Coastal Zone Management Act, many coastal zone management bills were introduced into Congress 。 Zigurds L. Ziles studied the legislative-political history of the Coastal Zone Management Act of 1972 and concluded that the CZMA did not emerge from a single concept recommended from similar interest, but evolved from unharmonized constituencies motivated by an abundance of concerns. Ziles grouped these constituencies and concerns into four categories: recreation, estuary protection, ocean development and land-use policy. ${ }^{3}$ Input from these general areas and recommendations found in the Stratton Commission Report, "Our Nation, Our Sea," combined to influence the contents of the CZMA as it was signed into law by President Nixon on October 27,1972 .

This paper focuses on a specific provision of the CZMA, Section $306(\mathrm{c})(8)$, and how well two approved state coastal zone management (CZM) programs (Massachusetts and Rhode Island) are complying with it。

Prior to the Secretary approving a State's CZM program he (she) must ensure that: 
"The management program provides for adequate consideration of the national interest involved in the planning for, and in the siting of facilities (including energy facilities in, or which significantly affect, such state's Coastal Zone) which are necessary to meet the requirements which are other than local in nature. In the case of such energy facilities, the Secretary shall find that the state has given such consideration to any applicable interstate energy plan or program."

In 1980 the CZMA is up for renewal, and a successful resolution of the meaning and place of the national interest provision in terms of the overall CZMA is fundamental to the program's continuation. ${ }^{4}$ Adding further importance to the national interest clause is the United States' quest for domestic sources of energy. The nation's vulnerability has been exposed by the Arab Oil Embargo of 1973 and it has become a national priority to decrease our dependence on foreign oil suppliers. Due to physical requirements of the energy industry, many facilities are located in the coastal zone. Basically then, there is a square-off between the pro-development energy industry and the preservation minded State CZM programs。

The national interest controversy has been pushed further into the limelight by a recent series of lawsuits brought by the American Petroleum Institute against the Federal Government, in reference to several State CZM programs. The suit, heard in Federal District Court, sought to enjoin Federal approval of these programs and thus terminate the flow of funds from the Federal Government necessary for program administration. The suit was decided in November of 1978 in favor of the Federal Government.

The scope of this study will entail a review of the literature, an analysis of the history and purpose of the national interest provision, a discussion of the differing interpretations of the national 
interest provision, and program evaluations, which will involve an investigation of the disposition process for national interest related applications. Lastly, conclusions and recommendations will be made towards aiding each state in its compliance with the provision. Literature dealing with the history and purpose of the national interest clause is scant at best; however, much information can be found in the legislative history of the CZMA. Further information has also been generated from examination of regulations and comment periodical responses from interested parties.

It is my hope that this paper can contribute to the resolution of the national interest controversy, so that the United States can proceed with effective coastal resources management as well as a productive energy program。 
CHAPTER I

THE EVOLUTION OF THE NATIONAL INTEREST PROVISION; PROBLEMS OF INTERPRETATION 
Due to the wide difference of opinion regarding the proper place and weight of the national interest clause in the overall Act, the legislative history of the CZMA as amended is reviewed in detail.

Indirect reference to the national interest can be discerned in the House Report's 1972 statement on the purpose of the CZM legislation. 5

"The purpose of the legislation is to encourage the various coastal states...by assisting the States, in cooperation with Federal and State governments and other vitally affected interests, in developing land and water use programs for the zone, including unified policies, criteria, standards, methods, and processes for dealing with 1 and and water use decisions of more than local significance."

Decisions of "more than local significance" may be subject to different jurisdictional interpretations: those on a regional scale and those that supercede regional impacts to have national implications. These two concepts are not mutually exclusive. It may be helpful to look at them in a cumulative sense, ie., a project of regional benefit may not be of national interest, however, a project of national interest will probably be comprised of one or more regional benefits.

The regional benefit clause Sect. 306(c)(2) seems to have been installed as "back-up" to the national interest provision. 6

"prior to granting approval, the Secretary shall also find that the program provides...(2) for a method of assuring that local 1 and and water use regulations within the Coastal Zone do not unreasonably restrict or exclude land and water uses of regional benefit."

If Sect。306(c)(2) were not installed, the national interest clause could be emasculated by local regulations designed to exclude development of more than local significance. There is no explicit statement in the legislation limiting the national interest and regional benefit provisions; however, it seems clear that Congress intended the two concepts to work towards the same goal. The difference is in method and 
scope, not intent. The relationship between the national interest and regional benefit will be discussed further in the next section when the relevant regulations are examined.

The foundation for the national interest clause is constructed in the Congressional findings section of the CZMA. Section 302(a) states that:

\footnotetext{
"The Congress finds that...there is a national interest in the effective management, beneficial use, protection and development of the Coastal Zone."
}

The 1976 Amendment to the CZMA added further reference to the national interest in the Congressional Findings sect。302(1) states that:
"The national objective of attaining a greater degree of energy self-sufficiency would be advanced by pro- viding federal financial assistance to meet state and local needs resulting from new or expanded energy activity in or affecting the Coastal Zone."

The Declaration of Policy as stated in sect. 303 of the CZMA further alludes to the national interest as the goals of the CZMA are described "national policy。" Such reference, designed in 1972, helps lay the groundwork for a more focused approach to the national interest concept regarding national energy policy。

The 1972 legislation did not foresee and could not adequately provide for the intense domestic search for energy precipitated by the Arab oil embargo of 1973. By their very nature many energy facilities must be situated in the coastal zone. Indeed, many oil companies will probably take advantage of the opportunity afforded by the Secretary of the Interior's outer continental shelf (OCS) lease sales, to explore for new oil and gas reserves, thus directly impacting coastal areas. The 1976 Amendments strive to strengthen the CZMA of 1972 by allowing it to cope with new pressures and demands, particularly those con- 
nected with energy。 As revised by the 1976 Amendments, the national interest clause, sect。306(c)(8) explicitly addresses the national interest as a subject to be reckoned with when planning and siting facilities necessary to meet requirements other than local in nature. The national interest clause is the source of great consternation because of its nebulous wording. It requires "adequate consideration" of the national interest. Obviously such wording is subject to varying interpretations.

What did Congress mean by adequate consideration? The legislative history shows that energy facilities are only one type of facility to which 306(c)(8) applies. The fact that energy plans are specifically mentioned shows Congress reacting to the energy crisis as a top priority. Furthermore, in view of sect. 309, which provides for interstate planning agreements and compacts, the importance of fully considering the plans and programs of interstate agencies as they relate to energy facilities is very consistent. It seems that the requirement for consideration of interstate energy plans or programs is not exclusive. Regulations may also be promulgated that require interstate plans and programs to be considered for the siting of other facilities. Regarding the adequate consideration phrase, the legislative history comments,

"Consistent with the intent of the Act, the Committee has not required automatic acceptance by Coastal States of these interstate energy plans and programs, but on the other hand, the requirement is that the consideration be adequate, not superfluous."

When drafting the legislation, Congress sincerely believed in the national importance of enacting coastal zone legislation. Representative Murphy $\left(N_{0} Y_{0}\right)$ reminded his colleagues in 1972 that, in a general sense, the coast, (together with the immediately adjacent land and 
water areas) is the nation's most valuable geographic asset. Such forthrightness is all well and good, however, Congress should have been more specific in requiring consideration of the national interest. Congress'ambiguity here could possibly result in circumvention of Coastal Zone Management goals. The burden of interpreting and implementing the national interest provision thus fell on the shoulders of the Office of Coastal Zone Management (OCZM), a division of the National Atmospheric and Oceanic Administration in the Department of Commerce. Granted, the OCZM was probably very capable of implementing the decision as they saw it, however, when left to regulations, the national interest issue became vulnerable to different interpretations, as well as input mechanisms, such as comment periods. Examination of the regulations attempting to implement the national interest provision together with comments from parties involved will, hopefully, bring into perspective the special significance of the national interest provision in light of the goals of the entire act.

The Federal Register sets forth the regulations with which states must comply pursuant to the national interest and regional benefit provisions of the Act。 8

Section 923.57 provides for "consideration of the national interest." In order to meet the requirements of sub-section $306(\mathrm{c})(8)$ of the Act, states must:

1. Describe which national interests, in the planning for and siting of facilities (which are necessary to meet requirements that are more than local in nature) were considered during program development and the sources relied upon for such consideration.

2. Indicate how and where the consideration of these national interests is reflected in the substance of the management program, including, where appro- 
priate, indication of when and where national interests in identified facilities may compete or conflict with other national interests in coastal resource conservation. In cases of such conflict, the program shall indicate how the conflict has been or $c$ an be weighed and resolved。

3. Describe a process for continued consideration of identified national interests (in facilities which are necessary to meet requirements that are more than local in nature) during program implementation, including a clear and detailed description of the administrative procedures and decision points where such interests can be considered.

States shall, in addition to the above, (Pursuant to $923-52(\mathrm{c})$ :

1. Consider any applicable interstate energy plan or program developed pursuant to section 309 of the Act

2. Meet the requirements for an energy facility planning process pursuant to the requirements of 923.14 except that

A. States with a management program approved prior to October 1, 1978, that do not meet the requirements of sub-section 305(b)(8) of the Act shall.

1. Describe existing or developing management program standards or policies as these apply to energy facility planning and siting; and

2. Describe briefly the status of the planning process required pursuant to sub-section 305 (b) (8) of the Act.

The Congress intended the above planning process to complement the evaluation of national interests pursuant to sub-section $306(\mathrm{c})(8)$ of the Act.

Section 923.13 of the Regulations lays down the requirements necessary for compliance with the Regional Benefit clause。 9

A. In order to meet the requirements of sub-section $306(c)(2)$ of the Act, States must 
1. Identify what constitutes uses of regional benefit; and

2. Identify methods that will assure that local 1 and and water use regulations do not unreasonably obstruct or exclude 1 and and water uses of regional benefit

.... B。 Comment. States have a number of options with respect to identifying uses of regional benefit as required in (A) (1) above....Whatever approach a state chooses, the basic criteria for identifying uses of regional benefit should be twofold (1) Effect on more than one local unit of government (effect may be considered to be of a multi-county or intrastate nature) and (2) direct and significant impact on Coastal Waters. Using these criteria, States could identify those uses they perceive will affect or produce some regional benefit.... Such activities as regional waste treatment plants, multi-county garbage disposal sites or landfills might be identified under this approach.

These same uses or other uses might be identified on the basis of plans adopted by areawide agencies.

As another approach, states may choose to define uses of regional benefit to include facilities in which there may be a national interest in their planning and siting。 OCZM uses the comment mechanism in the regulations to elaborate on the regional benefit clause.

C. Comment. Once uses of regional benefit have been identified, states must provide a method for assuring local regulations do not unreasonably restrict or exclude such uses. Requirements are discussed in 923.43 of the regulations. Section 923.43 of the regulations

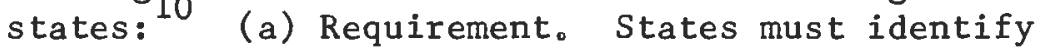
those techniques, including legal authorities, that will be used to assure that unreasonable restrictions or exclusions by local land and water regulations shall not be sustained. An example of such authority could be the drafting of statewide siting laws that supercede local regulations when necessary.

The above regulations are presented, not only for clarity due to further refecences to them, but to show the ambiguities that are created by the use of the "comment" mechanism. 
Regulations are supposed to set down legally enforceable guidelines so that authorities designated to enforce the legislation will do so in harmony with the intent of Congress. In addition to legally enforceable guidelines (housed under the "Requirement" sections) help in understanding of the comments is often proffered. The regulations pertaining to the national interest and regional benefit create problems of enforcement because the "Comment" sections contain what appear to be requirements. Such ambiguity can result in a state's interpreting the regulations in a manner which circumvents the intent of the pertinent provision.

Now that the intent of the Congress has been explored, and requirements (and Comments) for compliance with the national interest provision have been set down, it will be helpful to see how other interested parties interpret the clause.

COMMENTS OF THE PETROLEUM INDUSTRY ON INTERIM FINAL COASTAL ZONE MANAGEMENT PROGRAM DEVELOPMENT AND APPROVAL REGULATIONS (15 CFR PART $9234 / 19 / 78$

The American Petroleum Industry's (API) chief complaint is that the regulations fall short of meeting the "statutory requirement" that state programs consider the national interest through the use of legally enforceable provision. The API wants tougher standards imposed on state programs to insure that the national interest in planning and siting energy facilities is adequately considered.

API asserts that allowing general enhancement policies, as op posed to legally enforceable requirements, add to confusion on the part of decision-makers. API cites Sect。923(a)(2) of the regulations to demonstrate the "dilution" of the Act's requirements brought about 
by the national interest provision.

"That the policies, standards, objectives and criteria upon which decisions pursuant to the program will be based are.. osufficiently specific to provide (ii) a clear sense of direction and predictability for decision makers who must take actions pursuant to the management program。"

API takes a holistic stance in calling for comprehensive treatment of the national interest provision, in keeping with the Act's intent as stated sect. 302(h) "Congressional findings" which states that unified policies are crucial for dealing with land and water use decisions of more than local significance. Specifically, such comprehensiveness would entail simultaneous evaluation to insure that the requirements of $305(\mathrm{~b})(8)$ (requiring an energy facility siting process), 306(c)(8) (requiring adequate consideration of the national interest in facility siting), and 306(b)(2) (requiring assurance that local regulations do not unreasonably restrict or exclude uses of regional benefit) are looked at in context。

Backing up this three-pronged approach to adequate consideration of the national interest, is sect. $307(\mathrm{~h})$ which provides that in case of serious disagreement between any federal agency and a coastal state, in the administration of a management program approved under section 306

\footnotetext{
"The Secretary, with the cooperation of the Executive office of the President, shall seek to mediate the differences involved in such disagreement."
}

Following its holistic stance, API further suggests that the above approach be dealt with in relation to the requirements of $306(\mathrm{~b})(2)$, that state programs contain a definition of permissible uses of the coastal zone. 
API has taken a rational approach in presenting its case for a legally enforceable provision to adequately consider the national interest. No one can argue successfully that the national interest should not be looked at in a comprehensive nature. The crux of the argument is: to what degree should the national interest provision be made enforceable? When sect. 306(c)(8) was conceived in the 1976 amendments, there was no alteration of sect. 302(a) where Congress found that:

"There is a national interest in the effective management, beneficial use, protection, and development of the Coastal Zone."

306(c)(8) then, was meant to be enveloped by Sec. 302a。 Therefore, the national interest provision has to be interpreted within the broader congressional finding. To look at and interpret 306(c)(8) superficially could result in the emasculation of the ultimate Congressional finding as stated in 302(a), a finding from which 306(c)(8) was derived.

The 1976 amendments were specifically aimed at dealing with the nation's quest for domestic sources of energy. 306(c)(8) was a response to the anticipated siting of energy facilities on the coast, and coupled with this response was Section 308 which created the Coastal Energy Impact Program (CEIP). The CEIP was designed in light of $302(a)$ in that it provided financial assistance to states and localities to mitigate adverse impacts resulting from new or expanded energy-related activities. Congress did not want the national interest provision to act as an incentive for more energy facilities on the coast; indeed, it felt a "disproportionate" share of facilities existed. 11 
API makes some valid points; the only aspect of their presentation that I question is that of orientation. API can be commended for its holistic analysis, however, it undertakes its scrutiny by viewing the Act through the eyes of the National Interest provision rather than from Congress' point of view.

COMMENTS OF THE EDISON ELECTRIC INSTITUTE ON INTERIM-FINAL REGULATIONS ON "STATE COASTAL MANAGEMENT PROGRAMS DEVELOPMENT AND APPROVAL" (15 CFR, 923: 43 FED。REG。 8377; March l, 1978)

The Edison Electric Institute (EEI) echoes some of the complaints of API; however, EEI's method of analysis is narrower in scope. EEI scrutinizes the regulations pertaining to the national interest from the vantage point of its impact on the electric industry. EEI is less concerned with implementation of various sections of the Act in a cohesive fashion. EEI's approach may be paraphrased: "your regulations affect me in this way, it's unfair, and I want something done."

EEI asserts that the Office of Coastal Zone Management (OCZM) violated the Administrative Procedures Act by drafting regulations which are arbitrary, capricious, and discriminatory in their treatment of electric energy facilities. First, EEI claims the regulations arbitrarily and capriciously fail to define uses of regional benefit to include national interest facilities such as electric generating plants, whose benefit is universally greater than local in nature。 Secondly, EEI asserts that in excess of statutory authority, the regulations create a "national interests balancing" test and in an abuse of discretion, discriminatorily impose it only on prospective energy facility use of the Coastal Zone. 12 
EEI's contention here is that if a national interest balancing test should be required of prospective energy facility use of the coastal zone, it must also be required for all other uses。 EEI also feels that the regulations implicitly state that the balancing should always be in favor of the environment.

EEI cites the Congressional finding $302(a)$ as the rationale for $306(c)(8)$ but feels that such a linkage has resulted in "distortions" in the regulations. EEI finds that sect. 306(c)(8) has wrongly been forced into being a microcosm of the entire management program。 National interest becomes national interests. EEI further complains that $306(\mathrm{c})(8)$ is broadened by the addition of a totally new concept brought out in $923.52(\mathrm{~h})$ "resources in which there may be a national interest." 13

In assessing the energy facility planning process (EFPP) required in sect. 305(b)(8), EEI feels that the process should assimilate the facility identification and consideration features pursuant to the national interest clause, together with a mechanism for incorporating the legal authorities and techniques used by the state pursuant to the regional benefit provision. EEI sees the EFPP as the implementing arm for sections 306(c)(8) and 306(e)(2)。 EEI's main contention is epitomized by its objection to section $923.52(a)$ of the regulations, which state that the Act presumes a balancing of national interests in such facilities.owith federal, state and local concerns involving adverse economic, social or environmental aspects. EEI astutely points out that no citation to the Act or its legislative history is given in support of that regulation. EEI asserts that $306(\mathrm{c})(8)$ does not require balancing of the national interests. Rather it requires 
adequate consideration of the national interest in facilities including energy facilities. EEI counters that if this balancing is to be required of energy facility components of a state program, it should also be required of environmental protection components. 14 EEI suggests that, in order to properly implement section $306(c)(8)$, states must establish legally enforceable administrative procedures which assure adequate consideration of the national interest。

Like API, EEI makes some very good observations, especially concerning the EFPP, however, EEI's remarks are colored by vested interests. For instance, EEI objects to $306(\mathrm{c})(8)$ being a microcosm of the entire act, and national interest becoming national interests. EEI does not elaborate upon why they object. It seems perfectly normal for a broad finding, such as 302 (a) to be brought down to scale for purposes of implementation. New domestic energy development has been the first test of the national interest on a specific basis. Is not the national interest composed of national interests? Section 302(a) would not have any meaning if it could not be applied to specific management problems encountered in the operation of a program.

As for further "distortions," such as the concept of resources in which there may be a national interest, it seems as though EEI should be pleased. EEI continually calls for consideration of the national interest in other facilities and areas of preservation or restoration as a matter of fairness since electric facilities have been singled out. The concept of resources in which there may be a national interest demonstrates at least a step in this direction.

OCZM has taken heed of several of API's and EEI's comments, and recent changes in the regulations show this. Section 923.3 of the 
development and approval regulations, March 1, 1978, Part II, has been added to in sub-section $923.3(\mathrm{a})(3)$ with the requirement that:

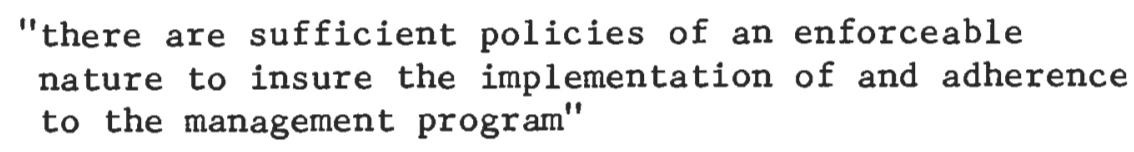

OCZM has taken a further step by adding a new requirement to the regulations which will be issued in March, 1979. Upon issuance in March of 1979 , states will be required to solicit view from all relevant local, state and federal agencies to insure that adequate consideration of facilities with significant effects more than local in nature are considered. This requirement will not satisfy all of API's and EEI's complaints, especially since the Coastal Management Agency is not forced to adhere to recommendations from various governmental agencies. JUDGE KELLEHER'S INTERPRETATION OF THE NATIONAL INTEREST

$A P I, E E I$, and OCZM have varying interpretations of the national interest provision. We shall now see how United States District Judge Robert Kelleher interpreted the controversial provision by reviewing the decision in American Petroleum Institute et al vi Robert W. Knecht et al, handed down August 31, 1978. API, along with Western Oil and Gas Association, brought action against three federal officials in their capacities as Secretary of Commerce, Administrator of the National Oceanic and Atmospheric Administration (NOAA), and Acting Associate Administrator of the Office of Coastal Zone Management (OCZM).

Plaintiffs seek declaratory and injunctive relief against the defendants' imminent grant of "final approval" of the California Coastal Zone Management Program(CCZMP). ${ }^{15}$ Plaintiffs contend that 
CCZMP is not a management program within the meaning of Section $304(11)$ of the Act due to its failure to satisfy the requirements of sections $305(b)$ and $306(c)(d)$ and (e), and pertinent regulations regarding content specificity。 Plaintiffs also contend that the program has not been adopted by the state, as required by $306(\mathrm{c})(1)$. Furthermore, plaintiffs assert that the Final Environmental Impact Statement on the CCZMP was not subjected to formal notice and hearings。

The following review of Kelleher's decision will deal with plaintiffs' claim that the CCZMP did not meet the requirements of $306(\mathrm{c})$, specifically $306(c)(8)$ 。

Regarding Section $306(c)(8)$ of the CZMA, plaintiffs read it to mean that before a state can receive 306 approval, it must "affirmatively" commit itself to accommodating the national interest in the siting of (energy) facilities. Plaintiffs contend that the California Program fails in this regard by its overall lack of specificity. Plaintiffs assert that such vagueness, combined with California's alleged antipathy to energy development, gives the Coastal Commission a "blank check" to effectively veto any exploration or development activities it deems as violating the consistency requirement of section $307(c)(3)$ 。

Defendants countered that the plaintiffs' call for an affirmative commitment is wrong as a matter of $1 \mathrm{aw}$, and that the program does contain adequate consideration of the national interest. Judge Kelleher ruled in favor of the federal officials.

Plaintiffs felt that the 1976 Amendments to the CZMA Section $306(c)(8)$ resulted in making program approval contingent upon affirmative commitments. The 306(c)(8) amendments, however, do no more than 
place extra emphasis on the siting of energy facilities. There is no mandate concerning the level of specificity which a state must comply with in satisfying the national interest provision.

The court goes back to January 9, 1975 regulations to cite NOAA's position relative to Congress' intent concerning any type of commitment and the level of specificity concerning Section $306(c)(8){ }^{16}$

".othe requirement should not be construed as compelling the states to propose a program which accommodates certain types of facilities, but to assure that such national concerns are included at an early stage in the state's planning activities and that such facilities not be arbritrarily excluded or unreasonably restricted in the management program without good and sufficient reasons...No separate national interest "test" need be applied and submitted other than evidence that listed national interest facilities have been considered in a manner similar to all other uses, and that appropriate consultation with the Federal Agencies listed has been conducted."

In Judge Kelleher's view, Congress was attempting to encourage affected states to upgrade their plans relative to energy facilities. The CEIP was the primary mechanism to aid the states in achieving this goal. Kelleher also knocks down the quid pro quo notion held by the plaintiffs by citing section $308(1)$ of the CZMA。

"The Secretary shall not intercede in any land use or water use decision of any coastal state with respect to the siting of any energy facility or public facility by making siting in a particular location a pre-requisite to, or a condition of, financial assistance under this section."

What the American Petroleum Institute sought was, in effect, an increased level of specificity, which would amount to a zoning map. API feels that it is burdened because it has to expend large sums of money to insure that their plans are consistent with California's CZMP. Ideally, API wants to be able to see on a map exactly where 
they may carry on activities, and the exact nature of any conditions to development. While this approach seems mechanically sound, it precludes close consultation with the state regarding activities that will affect the coastal zone. Kelleher recognized this inherent conflict and summarily rejected API's notion of increased specificity. Kelleher reviewed the meaning of the national interest provision in light of the rest of the Act, and thus ruled favorably on OCZM's behalf. Contentions made by the plaintiffs and defendants were born of a fundamental difference in orientation. Plaintiffs viewed the case through the eyes of the national interest provision, whereas defendants saw the national interest clause as it fit into the whole Act. Discussion of the literature concerning the national interest would not be complete without mention of a study forthcoming from the Center for Technology and Resource Policy at Stanford University。 Jeffrey $D$ 。 Roughgarden is working on a 3 volume essay dealing with the democratic siting of national interest energy facilities. Volume 2, Conceptual Foundations was reviewed for this study. Volume 1 is not relevant to this discussion and Volume 3 is not completed.

Roughgarden takes issue with the CZMA's use of the national interest concept. He feels the conflict aspect of the various national interests is over-emphasized. In his convoluted way, Roughgarden proceeds to suggest that there are no conflicting national interests.

"As noted in Chapter 3, the interests of an individual can be in conflict only if his personality is not well integrated. In the case of the nation, national interests are in conflict only if the nation is in some sense schizophrenic.To speak of conflicting national interests is to suggest that the union has dissolved. In fact, the interests of the nation are not in conflict with each 
other, rather the process of determining what is in the national interest involves resolving the conflicting interests of the various factions which make up the nation"17

Such mental meandering is common in Roughgarden's paper. Roughgarden believed that the siting of a facility is in the national interest only if it is in the interest of each party with effective veto power over the construction and operation of the facility. He feels that bargaining is the best and final means of conflict resolution because it reflects the current distribution of power and because the outcome of bargaining is unanimously agreed upon。 18

Roughgarden's theoretical approach is quite stimulating. But how is it linked to the present system for effective implementation? Possibly these questions are answered in Volume 3. An indication of the usefulness of Roughgarden's work may be the fact that the office of Coastal Zone Management discontinued funding for the study。 OCZM felt that the study was becoming too unrealistic and was of little value in resolving the existing controversy surrounding the provision. 19

In sum Roughgarden's work is largely theoretical and is quite hard to relate to the existing regulatory structure.

Before moving on to the Massachusetts and Rhode Island programs, it may be helpful to review briefly how the national interest provision relates to the rest of the Act, thus aiding the state program in effective coastal zone management.

Compliance with Section $306(c)(8)$ depends upon the state program's incorporating a planning process designed to enable the state to consider adequately the national interests in facility siting. Such a process does not imply intercession in specific siting decisions, 
although that may be the eventual effect. This planning process has to be undertaken within the context of the Act's general finding in subsection 302 (a) that there is a national interest in the "...beneficial use, protection and development of the coastal zone。"

In terms of priorities in the Act, sub-section $302(\mathrm{~g})$ gives

"high priority" to the protection of natural systems. Since the siting of facilities (particularly energy facilities) may run counter to protection of natural systems, there must be an effective balancing of these interests within the Act。 The Department of Energy noted in its comments on the proposed regulations: 20

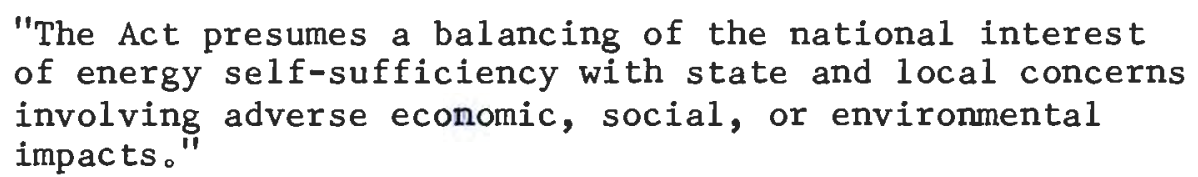

Implementation of the national interest clause is currently dependent upon the administering agencies' required efforts to consult with federal and state agencies, as well as relevant industries and other entities, regarding the demand for facilities that are more than local in nature.

Another way for states to incorporate the national interest provision in their programs is to assess the geographic configurations of the coastal zone, along with its dimensions. The current distribution of facilities and their dependence on the coast should also be determined. An illustrative list of facilities in which there may be a national interest is provided in the regulations as a guide for states seeking to determine an equitable balance for facilities in light of the content of the Act。2I 
- National Defense and Aerospace

- Energy Production and Transmission

- Recreation

- Transportation

- Regional Water Treatment Plants

It may also be mentioned that, while undertaking the national

interest planning process, states should take time to look beyond their borders. That is, a more regional viewpoint in addressing the national interest, particularly in energy facility siting, may prove more efficient, as well as more true to the CZMA's "high priority" of protecting the natural systems。 
Footnotes

1. Joseph Franke1, National Interest, po20。

2. Marc Jo Hershman and James A. Feldmann, Coastal Management Readings and Notes, p. 34

3. Marc J. Hershman and James H. Feldmann, Ibid p。 36

4. Discussion with Robert Knecht, Associate Administrator, office of Coastal Zone Management, Department of Commerce.

5. House Report No. 92-1049, 92nd Congress 2nd Session 18, (1972), Coastal Zone Management, p. 9.

6. Coastal Zone Management Act of 1972 (P.L。94-370)

7. Legislative History of the Coastal Zone Management Act of 1972, as amended in 1974 and 1976 with a section by section index, p. 762 .

8. Federal Register, Department of Commerce, National Oceanic and Atmospheric Administration, State Coastal Management Programs Development and Approval, Wednesday, March 1, 1978, Part 11, p。 8414 。

9. Federal Register, Ibid p. 8399.

10. Federal Register, Ibid p. 8410

11. HoR。 3981, The Committee on Merchant Marine and Fisheries, No。 $94-878$ at $45-46$ 。

12. Edison Electric Institute Comments on Interim-Final Regulations on "State Coastal Management Programs Development and Approval" ( 15 CoF。F。923; 43 Fed。Reg. 8377 et seq. March 1, 1978) p。3。

13. Edison Electric Institute Ibid po 10.

14. Edison Electric Institute Ibid po 43.

15. Memorandum of Decision and Order, American Petroleum Institute et al V Robert W。 Knecht, et al。, U。S。Dist。Ct。, Central District Ca., August 31, 1978.

16. 15 CoF。 $_{\circ}$, Sec. 923.15 (b), January 9, 1975.

17. Jeffrey Do Roughgarden, Energy Facility Siting and The National Interest, Volume 2 Conceptual Foundations, Section B. National Concerns, Preferences, Objectives and Interests。(No page 非)

18. Jeffrey D。 Roughgarden, Volume 2 Conceptual Foundations Section D. Contests, Bargaining and the National Interest (No page 非) 
19. A brief interview with Roughgarden revealed that his recommendations are an outgrowth of the view that the intent of Congress as displayed in the national interest provision is fundamentally wrong. It seems that Roughgarden's recommendations can only be achieved if there is a widespread change in values within our democratic system as we know it today.

20. 43 Fed。Reg。 Opcit 8379.

21. 43 Fed, Reg。 8414. 
CHAPTER II

PROGRAM EVALUATIONS 
A thorough investigation of Massachusett's and Rhode Island's fulfillment of the national interest provision should require a threestage analysis. First, each state program or Final Environmental

Impact Statement, should be reviewed to identify any policy statements regarding the national interest. The document would then be examined for its compliance with Federal Regulation $923.52(\mathrm{~b}) 1,2$ and 3, which stipulate what each state must do to meet the requirements of $306(1)(8)$ 。 The states must:

1. Describe which national interests in the planning for and siting of facilities (which are necessary to meet requirements that are more than local in nature) were considered during program development and the sources relied upon for such consideration;

2. Indicate how and where the consideration of these national interests is reflected in the substance of the management program including, where appropriate, indication of when and where national interests in identified facilities may compete or conflict with other national interests in coastal resource conservation. In cases of such conflict, the program shall indicate how the conflict has been or can be weighed and resolved;

3. Describe a process for continued consideration of identified national interests (in facilities which are necessary to meet requirements that are more than local in nature) during program implementation, including a clear and detailed description of the administrative procedures and decision points where such interest can be considered.

In meeting the requirement for adequate consideration of the national interest in the planning for and siting of energy facilities the states shall also:

1. Consider any applicable interstate energy plan or program developed pursuant to section 309 of the Act.

2. Meet the requirements for an energy facility planning process pursuant to the requirements of 923.14 .

Second, State Coastal Zone Program heads should be interviewed to 
determine whether there are any informal compliance procedures not discussed in the program. Such an interview process allows the state to update the FEIS in terms of their compliance with $306(\mathrm{c})(8)$ 。

Third, specific proposals should be examined to discern exactly what the level of compliance is and what methodology was used, in adequately considering the national interest in the siting of facilities. An analysis of the types of comments and subsequent actions taken regarding a specific facility proposal would help to show the feasibility of Section 306(c)(8)。Indeed, if all three stages were undertaken, a thorough analysis of the implementation of a federal mandate would be the result。

The accomplishment of objective three has been thwarted in this paper because there has not been any proposal with a national interest nature in either state. When this paper was first conceived, there was every reason to believe that there would be concrete examples to review by early 1979. Litigation brought by Massachusetts has prevented OCS activity from occurring on Georges Bank, resulting in a delay in anticipated onshore ocs related facilities. My approach to the national interest controversy was not altered, however, since I was primarily interested in each state's process for considering the national interest. Instead of asking, "How did you consider the national interest in this proposal?" I asked, "If you were to get a proposal for this type of facility tomorrow, how would you go about considering the national interest?" It is important to have the states aware and thinking about their national interest obligation now, for upon the resolution of the suit, oil companies may be swiftly swooping down on Massachusetts and Rhode Island. Hopefully, the 
following analysis and interviews will help prod the states to start preparing for the potential onslaught of ocs related activities. Rhode Island and the National Interest Provision:

Politically, Rhode Island seems very willing, almost eager, to see OCS activity begin on Georges Bank。 OCS activity is seen as a potential economic boon here, especially since Davisville, R.I。 was selected as the support base for exploratory rigs presently operating on the Baltimore Canyon (off the New Jersey Coast)。 To Rhode Island's consternation, even more OCS related activities are being delayed from locating at Davisville because of Massachusetts' successful plea for an injunction on further OCS activity on Georges Bank. A Rhode Island Department of Economic Development (DED) study conducted for the Coastal Resources Management Council (CRMC) proclaimed that Quonset/ Davisville redevelopment is an "essential cornerstone to economic recovery。"1. The Governor's Administration has also come out in favor of such development. Governor Garrahy of ten referred to OCS activity and Rhode Island's wishes to benefit from it as also serving the "national purpose."2。 Politically, the stage is set in Rhode Island for accormodating as much development as possible from ocs activity.

Rhode Island can afford to be an avid fan of ocS related activity. The Quonset/Davisville site (formerly Navy property), is prime for coastal industrial activities. Presently there are approximately 75 businesses operating at the site. ${ }^{3}$. Supply boats operate out of slips there, but there has yet to be any major ocs related facility proposed. Such proposals will be forthcoming when and if there is a significant find。 
According to DED, those OCS related facilities which could be appropriately sited at Quonset/Davisville are: ${ }^{4}$

1. temporary and permanent service bases

2. cold steel platform fabrication yard

3. pipe lay down and coating yard

Facilities deemed of low priority are:

1. gas processing

2. Petroleum terminal

3. oil refinery

In a sense, Rhode Island has pre-ordained "proper" uses for the Quonset/Davisville sites。 CRMC should be commended for pre-determining which uses are best in light of the goals of the CZMA. However, the CRMC must also insure that proposals for the above facilities receive equally thorough treatment when considering the national interest.

Rhode Island had several approaches in considering the national interest during program development. CRMC initiated a formal federal participation program which consisted of four state-federal workshops held between November, 1975 and February, 1976. ${ }^{5}$ Further insuring that state and federal comments were solicited and used in the development of the program was the creation of a state-federal coordinator. The Coordinator's position was vacated about the time of program approval and still remains so. ${ }^{6}$

The Federal Advisory Committee was established in the spring of 1976. This Committee provides an open forum for federal agency comment on, and participation in, Rhode Island's program development and implementation. The Federal Advisory Committee also serves as a mechanism for identification and resolution of state-federal differences. 
According to the FEIS the Federal Advisory Committee meets at a minimum of every three months. However, they have not met yet because of the lack of relevant proposals. Members of the Federal Advisory Committee consist of representatives of the federal agencies listed in Rhode Island's program under "Federal Agency Mission Descriptions/Policy Statements Section" (discussed below). Capping off the federal-state link is the A-95 review process carried out by Rhode Island Statewide Planning. A-95 review attempts to foresee conflicts resulting from federal and state related actions within the state, and is authorized under section 701 of the Housing Act of 1954 as amended.

The main information base for the CRMC in fulfilling the national interest provision and accompanying regulations are mission descriptions and policy statements submitted to it by affected federal agencies. Eight policy areas are listed, along with the federal agencies involved. The policy areas and related federal agencies are: ${ }^{\circ}$

1. Recreation: Bureau of Outdoor Recreation, National Park Service, Fish and Wildlife Service, Corps of Engineers, Forest Service U。S。D。A。

2. Historic/Cultural - Aesthetic/Conservation: National Park Service, Fish and Wildlife Service, National Marine Fisheries Service, Corps of Engineers

3. Food and Fiber: Soil Conservation Service, Fish and Wildlife Service, National Marine Fisheries Service, Army Corps of Engineers, Forest Service U.S.D.A.

4. Defense and Aerospace: Department of Defense

5. Energy Production and Transmission: Federal Power Commission, Federal Energy Administration, Bureau of Land Management, U.S. Geological Survey, Department of Transportation, Energy Research and Development Administration, Nuclear Regulatory Commission, Corps of Engineers.

6. Interstate Transportation: Department of Transportation, Army Corps of Engineers, Maritime Administration, Interstate Commerce Cormission 
7. Mineral Resources: Bureau of Mines, Geological Survey, Army Corps of Engineers

8. Preservation of Life and Property: Federal Insurance Administration, National Ocean Survey, Army Corps of Engineers

The CRMC's plan lists those resources in which there is a national interest, and the federal agencies consulted in determining the salient features of the national interest in that resource. The CRMC's plan also details how each resource is applicable to Rhode Island's Coastal Resources Management Program. 8.

Rhode Island thoroughly complies with $923.52(\mathrm{~b})(1)$ and (2). The Final Environmental Impact Statement (FEIS) is admirably specific in regard to these two areas, however, the plan becomes less explicit in its treatment of $923.52(\mathrm{~b})(3)$. The FEIS does not describe a process for continued consideration of identified national interests during program implementation, nor does the FEIS provide a clear and detailed description of the administrative procedures and decision points where such interests can be considered. Such a process does exist at the CRMC, but, it had to be unraveled through personal interviews with CRMC staff.

The questions posed to the CRMC staff were: "What would be the process for considering the national interest in the event of a proposal for the construction of a platform fabrication yard?" "What administrative procedures would be conducted and where are the decision points?" Figure 1 depicts how Rhode Island would handle a proposal with a national interest。

The regional benefit clause is relevant at this point, for before a proposal can be made to the CRMC local permits must be obtained. The Rhode Island Coastal Zone Program is the mechanism which prevents towns 
from excluding uses of more than local significance. The Rhode Island plan states that any future modification of zoning ordinances by towns must be consistent with the Comprehensive Plan which, in turn, must be in general conformity with the goals, objectives and policies in applicable state plans. The Coastal Resources Management Program is the applicable state plan to which conformity is mandated. The CRMC, then, can continue to insure that there remains a sufficient number of sites to accommodate facilities in which there is a regional benefit. It should be noted that the CRMC does not have the authority to regulate zoning uses effected by towns prior to proposals for the location of facilities within which there is a regional benefit. The CRMC may intervene only when a town attempts to install exclusionary provisions in its zoning ordinances in response to a proposal to locate a facility (in which there is a regional benefit) within its borders. 
Rhode Island National Interest Process

Storage Facility - Figure 1

local permits must be obtained prior to

Council's review

if local regulations exclude the project, the federal advisory comnittee is designed to engage in conflict resolution tactics

CRMC Members

obtain copies of comments from interested entities

if testimony requires, more than one hearing is held

totally new evidence may be submitted here

CRMC sends assent and decision to those at public hearing who requested one
Proposal Received

20 day notice of public hearing

public hearing is held

sub-committee makes recommendation to full Council at next monthly meeting

following months action is put on agenda

decision material sent to legal counsel for write-up of findings of fact and decision

30 day appeals process begins - appeals are heard in $R_{0} I_{0}$ Superior Court previously designated federal agencies notified state mailing list activated

30 day comment period begins upon notification

a sub-committee is designated by chairman to handle project

testimony at hearing recorded on transcript and mailed to all members of the Council

sub-committee attends hearing - answers questions monitors

if no new evidence is entered and the CRMC is ready, they will modify, approve or reject the proposal 
Presuming that the project proposal will secure local approval, the CRMC begins the process by mailing notices of the application to those federal agencies listed as concerned in the Coastal Plan. Notices also go out to those on the Council's general mailing list. State agencies, such as Statewide Planning, Department of Environmental Management are on this 1 ist, as well as numerous environmental groups. Industry representatives are also notified. For instance, in the case of a platform fabrication yard, the American Petroleum In.stitute is on the list and will be notified. Indeed, the petroleum industry is kept well informed concerning CRMC action because the Rhode Island Petroleum Institute's Executive Director is one of the 17 members on the Council. Those interested have 30 days to file comments regarding the proposed action with the Council. The rest of the chart is self-explanatory。

There is difficulty in pinning down exact decision points in the CRMC's consideration of the national interest. Decisions determining which federal agencies receive comments in the case of a proposed platform fabrication yard are already made in the Council's Coastal Plan. After examination of the 80 name mailing 1ist, all state interests are well represented. The key decision point in the whole process seems to be the CRMC's Chairman's appointment of a sub-committee to handle the platform fabrication proposal. Discretion must be used by the Chairman in assembling such a sub-committee, for it is they who attend hearings on the project and present their findings to the full Council.

Procedural regulations guiding the hearing process are commendable. Al1 public hearing testimony is recorded, and copies sent to al1 CRMC 
members. Therefore, it is not up to the Sub-committee to decide what information will be passed on to the rest of the CRMC. The CRMC also aptly allows for the presentation of new evidence, even at the meeting where they expected to vote on the matter. Introduction of new evidence would undoubtedly push the final decision back another month, however, the CRMC would have the discretion of deciding whether the evidence was presented in good faith or being used as a delaying tactic.

The final decision (that which modifies, approves or rejects the proposal) is made by the collective CRMC and is hard to scrutinize because there is no criteria which to judge their decision against. The Council needs a quorum of nine (out of seventeen) to vote on an issue, with majority ruling. 9

Rhode Island's Coastal Resources Management Council appears to comply adequately with the national interest provision. By meeting the requirements laid out in $923.52(\mathrm{~b})(1)(2)$ and (3). Granted the Council could be more explicit in its treatment of $923.52(\mathrm{~b})(3)$, but the process is there if you delve a little. Rhode Island also satisfactorily meets the requirements put forth in $923.52(\mathrm{c})(1)$ and (2)。 Point (1) is moot, since there is no applicable interstate energy plan or program developed pursuant to Section 309 of the Act. Point (2) is met through the requirements laid out in Section $610.2(\mathrm{c}$ ) of the Rhode Island Plan, which states that: 10

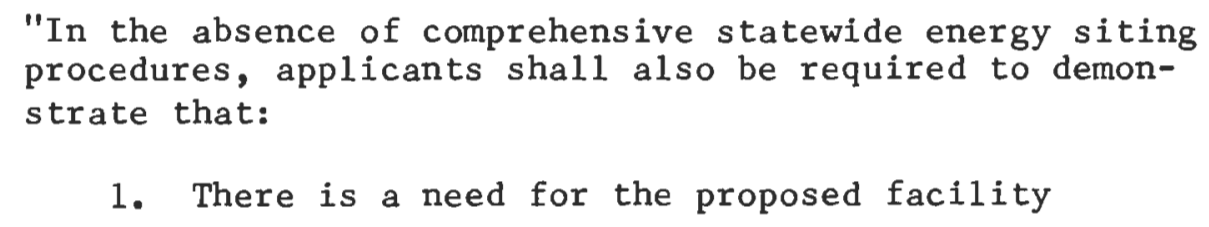


2. Impacts on public service requirements and instate employment opportunities have been identified and considered.

Reliance on the applicant to provide the statement of need could be risky. However, in the event of a large proposal, such as a platform fabrication complex, the CRMC can hire consultants to undertake studies. Rhode Island can safeguard itself in the event of a potentially large project by having its own assessment of need carried out. Statements of need for oil-related facilities posed a problem in Massachusetts, as well as in Rhode Island, due to the nature of the oil industry. Each time an oil company plans to construct a facility, it has to decide how big a scope to look at in assessing the need. If the company were to carry out a fully comprehensive need/impact assessment, it would have to look at the world supply。 What usually occurs is a regional evaluation of need. Even this can be difficult, especially in New England, when foreign elements play a major role in the regional petroleum industry. Thus, a statement of need should not be viewed as a state of the art study, but a practical evaluation on the part of the oil company, in terms of the solvency of the project at hand. Since the petroleum industry is in a state of flux, the required need statements should be closely examined. However, in the end, states must rely on the marketing sense of the private company.

Rhode Island has complied with the national interest provision well, however, concrete examples of such compliance are needed for an affirmation of this positive assessment. Rhode Island should not have to wait too long for this to happen, since the petroleum industry is currently hovering over the Baltimore Canyon, as well as preparing to strike at Georges Bank if Massachusetts drops its suit。 
Compliance with the national interest provision in the Rhode Island program did not take place in a vacuum, but was effected in light of the over-all goals of the CZMA. The Rhode Island Coastal Plan has designated valuable natural features and habitats for preservation and restoration. Rhode Island reiterates its willingness to accommodate the national interest in its plan by stating that it recognizes that coastal wet lands may have to be disturbed if the proposed activity is clearly in the public interest and no reasonable alternative exists。 11

Massachusetts and the National Interest Provision

The political back-drop in Massachusetts has changed drastically since this paper was first conceived. Governor Dukakis, a liberal Democrat much in tune with the environmental movement, was defeated by Edward King, a conservative Democrat, very much pro-business。 The policy of Massachusetts towards OCS development is now one of accommodation。 Ed King has stated publicly that he hopes Massachusetts Attorney General Francis X. Bellotti will drop Massachusetts suit against the Federal Government, which currently enjoins oil companies from engaging in OCS activity on Georges Bank, located approximately 70 miles off Nantucket Island. Because of internal administrative differences, the Massachusetts energy policy is somewhat fragmented.

Unlike Rhode Island, Massachusetts has passed energy facility siting legislation. The Energy Facilities Siting Council (EFSC) is the mechanism created by the legislation which will be responsible for implementing the national interest provision in most cases. One of Governor King's energy policies dealing with the EFSC will directly 
management policies in Massachusetts.

An environmentally-conscious Massachusetts did pass energy facility siting legislation in 1975, which created the Energy Facility Siting Council (EFSC) and gave the EFSC broad regulatory powers over the siting of energy facilities within the state. The EFSC emerged as crucial to this study in that it is the principal actor in considering the national interest in energy facilities。

Due to non-existent enabling legislation, the Massachusetts Coastal Zone Management Office is not legally recognized, and consequently has little clout in getting other state agencies to comply with its demands. The Office of Coastal Zone Management was created without the consent of the state legislature. The then Scretary of Environmental Affairs, (Evelyn Murphy) like the Governors, she served (Dukakis), believed in the merits of coastal zone management. The office is 80 percent funded from money granted by the Federal office of Coastal Zone Management。 Therefore, state legislative approval (and money) is not necessary for this office to function. The Massachusetts Office of Coastal Zone Management's lack of legal standing proves to be a crucial factor in its level of compliance with the national interest clause.

During its program development stages, Massachusetts Office of Coastal Zone Management made various efforts to consider adequately the national interest. A list of 35 federal agencies complled by the New England River Basins Commission was utilized by the Massachusetts Coastal Zone Management Program in their efforts to solicit comments helpful in determining the national interest. The program document (FEIS) does not contain a list of the agencies contacted. The FEIS 
also indicated that the MCZM office has been "deeply involved" in OCS oil and gas development process, and consequently engaged in a continual exchange with federal agencies, such as the Bureau of Land Management, Geological Survey and the Coast Guard. ${ }^{13}$ The FEIS further noted that it looked to the following sources in determining the national interest: 14

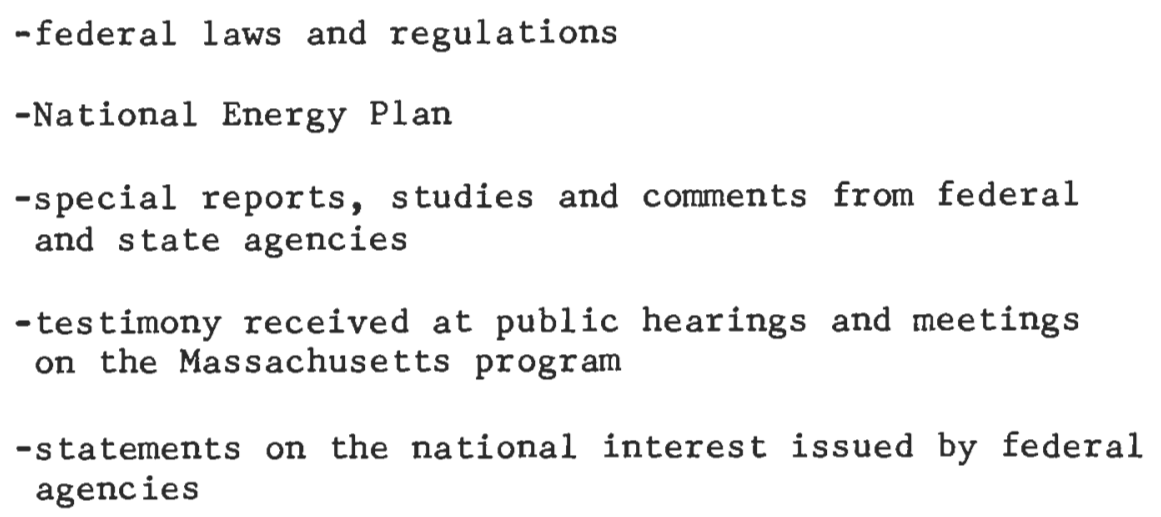

The FEIS does not detail what the statements from federal agencies pertaining to the national interest were, nor which agencies were involved. For continued consideration of the national interest, the FEIS outlined a five-step implementation procedure。 15

1. In order to balance national interests, MCZM undertook a study to determine areas for preservation or restoration and areas of critical concern. These designations consisted of 1 and uses such as salt marshes, dunes, beaches, barrier beaches, shellfish beds and salt ponds and fish spawning areas. Specifically, construction associated with tank farms, terminals, power plants, gas facilities and coal extraction could prove severly damaging in the designated ecologically sensitive areas. According to the FEIS, in the event of energy proposals in these areas, the environmental impacts will be given prime consideration by the Energy Facility Siting Council。 
2. Secondly, the Energy Facilities Siting Council examines tenyear forecasts of demand required of gas and electric companies and notices of intent to construct oil facilities. In reviewing forecast projections, the EFSC analyzes alternatives provided by applicants. Other methods of generating, manufacturing or storing gas or electricity are also investigated. Different strategies are examined that would promote either energy conservation and/or consumption, or maintenance of the status quo.

In its decision of whether or not to approve a long-range forecast, the EFSC has to meet five requirements (Chapter 164, Section $69 \mathrm{~J})$, and for notice of intent, three more requirements. The forecast requirements mandate that all information submitted, including environmental impact and demand projections:

1. is accurate and consistent with other companies

2. is consistent with current health, environmental protection and resource policies of the Commonweal th

3. provide the necessary supply

4. provide services at lowest cost

5. provide for minimum environmental impact

For notices of intention, the EFSC must find that:

1. sources of supply 1 isted are accurate

2. the project is financially sound

3. plans, including buffer zones or alternatives thereto, are consistent with current health, environmental protection and resource use and development policies as adopted by the Commonwealth。

3. Next, applicants proposing to construct energy facilities must secure all applicable state and local permit approvalso For 
example, Environmental Affairs Agencies have regulatory authority over certain resources, such as air, water, wetlands and tidelands. Local authorities have the responsibility of reviewing the proposal for conformance to zoning ordinances.

4. This step meets the regional benefit requirements of the CZMA as well as the national interest provision. To insure that procedures of step 3 do not unreasonably exclude such energy facility uses (which have more than local significance) there is an appeals process. If an applicant is dissatisfied with the local decision, an appeal for a Certificate of Environmental Impact and Public Need may be filed for. If the EFSC rules affirmatively on the petition, the Certificate is issued (with whatever conditions necessary) which overrides the state or local permit or license in question.

5. Federal Consistency: Should a Certificate of Environmental Impact and Public Need be sought on the basis of the denial or imposition of burdensome conditions by an EOEA agency, federal consistency concurrence will be issued if the EFSC has awarded the Certificate.

MCZM has complied with the national interest provision through the networking approach by utilizing the EFSC. Networking is a costeffective way of providing services with a minimum of duplication and overlap. However, care should be exercised in the delegation of duties to insure that those delegated have the power and incentive to carry out their assignment.

MCZM has put the burden of compliance with the national interest clause on the EFSC. The regulations promulgated pursuant to Section 306(c)(8) and 306(e)(2) of the CZMA 1972 as amended apply to those coastal states with approved programs. MCZM is an approved program 
federally, but it is not legally recognized on the state level。 Such non-recognition by the state has emasculated MCZM's ability to compel other state entities to aid MCZM in its mission.

"...The Council (EFSC) is bound to make its forecasts and site approval decisions in conformance with current health, environmental protection, and land use and development policies of the Commonwealth as set forth in the Constitution, general laws, and duly promulgated rules and regulations of responsible state, regional or local agencies having the force of law." 16

Because the MCZM program is not grounded in State statutes, and was created by an "end run around the legislature"17 (via the Secretary of Environmental Affair's promulgation of regulations not tied to a specific law), the EFSC has the latitude to decide whether or not to fulfill the national interest provision. Furthermore, the King Administration's proclamation to strip away all but basic review of proposed energy facilities could seriously impede MCZM's obligation to balance the national interests in such sitings.

The EFSC is the key component in MCZM's attempt to comply with the regulations issued pursuant to Section $306(c)(8)$. Since the national interest question, by and large, is handled by the EFSC, it is necessary to detail the actions the EFSC would take in the event of a proposal with national interest.

At this writing, Massachusetts, like Rhode Island, has not had to act on a proposal in the national interest. I will analyze the EFSC's process to see whether it is designed adequately to handle a proposal for a major oil facility。

The EFSC does not have unlimited jurisdiction over the siting of all energy facilities. EFSC can act only on those oil facility proposals worth $\$ 5$ million or more ${ }^{18}$ If a project is less than $\$ 5$ 
million, local police power can be used to decide whether or not the facility is sited. This jurisdictional split results in a fragmented attempt to fulfill the national interest and is discussed below. Composition of the Energy Facility Siting Council

Presently there are four Cabinet Secretaries on the Council, who are appointed by the Governor and preside for the length of his stay in office. The Secretaries of: Environmental Affairs, Consumer Affairs, Economic Affairs, Administration and Finance may soon be joined by the Secretary of Energy (now before the legislature), who will also function as Chairman of the Council. The six other members of the Council consist of three men experienced in gas (professor at MIT), electric (former head of Public Utilities Commission under a previous administration), and oil (Vice President of Badger Corporation - had previous oil experience in Europe) facilities. The major stipulation affecting these three is that they cannot derive more than $15 \%$ of their income from these areas. The final three must consist of one person experienced in the conservation and protection of the environment, one registered as a professional engineer, and one representing organized labor. These six persons are appointed by the Governor for terms of three years. 19

When ruling on an oil facility proposal, only eight Council members would vote: the four Cabinet Secretaries, the Environmental, engineering and 1 abor representatives, and the oil representive. A quorum of five is needed for a decision, with a majority needed for approval. $^{20}$ The electric and gas representatives are prohibited from voting on an oil facility, and vice versa, due to conflict of interest. 
The Energy Facility Siting Council And The National Interest Process

The EFSC has committed itself to considering the national interest in the development of energy resources by providing for such cognizance in its regulations。(Rule 83.2)

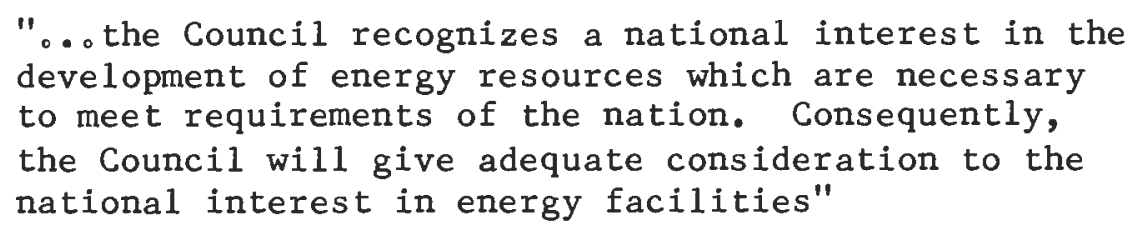

This is a clear-cut statement of policy, however, the permanence of this policy must be questioned. The Council may, at any time revise their regulations as it sees fit. If Governor King's appointees are intent on granting only basic reviews to energy proposals, they could delete their stated committment to fulfill the national interest provision. The Council could do this without violating the authority of the Massachusetts Office of Coastal Zone Management because MCZM has no legal authority. Massachusetts' Coastal Zone Management can't say to the Council, "You are not enforcing our statutes" because it doesn't have a legislatively created program. MCZM can say, "You are not acting in concert with the Commonwealth's development policies," but without much effect, since the EFSC could retort with the same statement. MCZM comes under the jurisdiction of the Secretary of Executive Office of Environmental Affairs, who is also a member of the EFSC. When the Council's regulations were drafted, Evelyn F。 Murphy was the Environmental Affairs Secretary and had orchestrated the "end run around the legislature," which created the state's Coastal Zone Program. Consequently, Murphy was very concerned that the two units work together. Now, with a new King-appointed Secretary of Environmental Affairs, there may be less interest displayed 
in keeping the Council and CZM in perfect harmony. The national interest process, then, is implemented at the whim of the Council, not by legislative mandate. This could prove deleterious to Massachusetts' coastal environment if King's administration is as pro-energy-development as it purports to be.

The burden of identifying the national interest in a facility is placed upon the petitioner in the Council's regulations。(Rule 73.2)。 For each facility (valued at least at $\$ 5$ million) covered by a petition, the following information shall be provided:

1. facility name and location;

2. predicted dates of commencement and completion of construction, and first commercial operation;

*3. the names of any local of other state agencies asserting or which may assert jurisdiction over the proposed facility, and a description of the asserted jurisdiction, including a reference to the statutory authority of the agencies

*4. the names of any federal agencies asserting or which may assert jurisdiction over the proposed facility, and a description of the asserted jurisdiction, including a reference to the statutory authority of the agencies;

*5 the names of any state or federal agencies for which an environmental assessment must be prepared。.。

*6 a description of any zoning by-laws in effect on the date of the petition and affecting the proposed site and any alternative sites considered. (This works towards meeting the regional benefit clause.)

*Relates to guidelines set by the National Oceanic and Atmospheric Administration for fulfilling the national interest.

When measured against the guidelines issued by the National Oceanic and Atmospheric Administration to the national interest, the Council's process seems adequate. The information required from the petitioner, however, is only part of the process. The process be- 
comes complete when the Council uses the information to generate input from all those concerned. Presently, the Council does not have its own list of agencies that should be contacted upon petition of a certain facility。 The Council utilizes its staff for reviewing the petitions to see if they are adequate, however, there are no guidelines for the staff to follow. Granted, the expertise of the staff is probably sufficient to spot gaps in petitions concerning adequate consideration of the national interest, but will the present expertise always be there? ${ }^{21}$

Once comments are generated and the procedural requirements are met which bring the petition before the Council for a final decision, the last phase of the national interest process begins。 (See process chart; Figure 2)。

The Council's regulations clearly delineate the type of information which must be provided by a petitioner. Unlike Rhode Island, it is easier to get an idea of what criteria the decision-makers utilize in deciding to approve, modify or reject a proposal. (Such criteria would be available in Rhode Island if there had been proposals in the national interest. Nevertheless, Rhode Island does not have explicit guidelines for such proposals。) 
Storage Facility - Figure 2

petition must fulfill requirements laid out in part 73 of EFSC's Regulations

petitioner deposits copy of petition in repository located in affected town

more hearings may be held upon request

notice given in at least 2 newspapers in vicinity of site in question

hearings officer may schedule pre-hearing conference for limit ation/simplification of issues deemed necessary or requested by any party

any interested person may participate in hearing upon written or oral request

copies of Tentative Decision are sent to every party and participating persons

party may at any time prior to a final decision move that the adjudicatory hearing be reopened for purpose of receiving new evidence
Notice of Intention filed 1 year prior to proposed construction date

Council sends out notices of petition

public hearing is held upon request in localities where sites are proposed - public hearing is held at least 14 days prior to adjudicatory hearing

notice of adjudicatory hearing - 21 day comment period

adjudicatory hearing is held in Boston - Hearings officer (appt. by Chairman of Council) presides Hearings Officer may extend the hearing process if deemed necessary

a party may file an objection to a Hearing officer's ruling within 2 days of notification of such ruling - 7 day comment period to every party and participating persons

"Action by Consent" Council quorum meets; majority signatures are needed for approval of a proposal, before final decision is issued if petition does not meet requisites, a new petition may be filed at any time

Federal and State Agencies deemed appropriate

appropriate entities listed on Council's mailing list

comments at this hearing are not provided to Council

Federal and State agencies deemed appropriate

appropriate entities listed on Council's mailing list

official transcript recorded for Council review

Hearings Officer issues a tentative decision to be submitted to Council
Council members review
Tentative Decision

upon its own motion Council may hold a hearing on the Tentative Decision

if majority is not reached petition is put on next meeting's agenda approval in accordance with part 72.9 (2) of Council's Regulations 
Figure 2 - (Cont.)

Counsel prepares findings

of fact, writes decision

30 day appeal period -

parties may seek judicial

review of a final Council

decision in Supreme Judicial

Court of Massachusetts 
A facility proposal for storage of oil or refined oil products will be used here as an example of what type of information the Council would use in making any decision. The following information shall be provided by such a petitioner: ${ }^{22}$

1. a general description of major structures and equipment comprising the facility and to be located on the site. (The general description shall be accompanied by such detailed descriptions and plans as are then available);

2. aerial photographs of appropriate scale showing the facility and site and its surroundings within a onemile radius of the site, designating current major land-use - patterns within the one-mile radius, and showing the location of proposed facilities within the site. (include written descriptions, keyed to said aerial photographs of developed areas, agricultural or other open areas, parks and recreation areas, areas designed by a governmental agency for protection as nature preserves or historic or scenic districts, zoning patterns, major transportation facilities, existing and proposed, serving the facility site, and provisions, if any, for buffer zones adjoining the site);

3. a statement enumerating the products to be stored at the facility, and the facility's designed annual capacity for each such product

4. U.S.G.S. topographical maps of scale $1: 24000$ depicting the site and all lands and waters within eight thousand $(8,000)$ feet of the site.

5. a general description of environmental protection equipment to be installed at the facility, and other measures to minimize damage to the environment;

6. a statement of the region in which crude oil or refined petroleum products stores at the facility are expected to be sold to retail customers

7. a statement of the measures, if any, to be taken to reduce the impact on transportation systems and to otherwise provide for an adequate transportation network, both in the vicinity of the facility and throughout the area where its products will be marketed. 
In addition, the petitioner (per Rules 73.4) "shall forecast the sales in the region...for each of the products to be manufactured, or services to be rendered by means of the proposed facility。"

According to Rule 73.5 of the Council's regulations, the petitioner shall provide an analysis of need for planned facilities. According to EFSC Deputy Director, Phil Shapiro, the Council does not examine the need requirement because the need is presumed if a petitioner so declares. Rule 73.6 provides that the petitioner issue an environmental impact analysis of the proposed facility。 Impacts described shall be:

1. impact of the proposed facility or alternative upon existing land use at the facility site... including the effects, if any, of the facility upon population or proposed land uses that will be foregone if the facility is built.

2. impact upon water and air resources, radiation levels, and noise levels

3. impact on existing transportation systems

4. methods used to dispose of solid wastes and the impact of such disposal on public and private facilities

5. The plans for expansion and construction of the proposed facility are consistent with the stated policy of the Commonwealth to provide a necessary energy supply for the Commonwealth with a minimum impact on the environment at the lowest possible cost.

It is not exactly clear how the Council goes about making the above determinations. The Council's staff is the vehicle for getting information to the Council, and would be carrying out the bulk of the investigating. Deputy Director Shapiro explained that the four Cabinet members on the Council go a long way towards fulfilling many of the requirements, as they represent the collaboration of the Commonwealth's resources, The Cabinet Secretaries have immediate access to all in- 
formation in their departments and can tap their respective departments at the Council's request. The Council's staff will utilize entities, such as the Security and Exchange Commission, Dun and Bradstreet, and Standard and Poor's publications in verifying the petitioner's financial information.

Given the above-mentioned inadequacies, Massachusetts' consideration of the national interest seems adequate, however, only an examination of an actual proposal will tell how adequate. 24

The major gap in Massachusetts' process regarding oil facilities exists due to the $\$ 5$ million floor placed on projects slated for Council jurisdiction. Projects worth $\$ 3$ million are not subject to national interest review. The project's fate would be in the hands of the local police power. State review would come into play if wetlands or waterways were affected. The Division of Water Pollution Control (jointly administered with EPA), and the Department of Environmental Quality Engineering ( $\mathrm{DEQE}$ ) would also be involved to insure proper pollution abatement. ${ }^{25}$ obviously, none of these agencies will look at such a project in keeping with the intent of the national interest provision. Massachusetts' "networking" system breaks down in oil facility proposals valued at less than $\$ 5$ million. There are no incentives or guidelines for local regulatory bodies to engage in scrutiny which fulfills the national interest clause.

William Clandaniel, an attorney with Massachusetts' Coastal Management Program, conceded that there is no process for considering the national interest in projects which do not come under the jurisdiction of the EFSC. This flaw hasn't been previously exposed because there haven't been any such projects proposed. However, with the injunction 
on the Georges Bank lease sale lifted, proposals may be forthcoming。 The "networking" system appears to be unmanageable in Massachusetts' attempt to comply with the national interest provision. This could prove troublesome for the state if confronted with such evidence by a party negatively affected by a local decision. Massachusetts' dilemma will be discussed further in the third chapter.

Massachusetts and Rhode Island have deficiencies in their processes which can be remedied, as will be discussed in the next chapter. There is one fundamental flaw common to both programs, however, which strikes at the very heart of the national interest question. Both states have set up a mechanism for generating comment from federal and state agencies and other local entities, but neither state has criteria with which to measure these comments. Specifically, neither state has legally enforceable guidelines delineating exactly when a facility involves the national interest. Comments from various agencies are fine, but how do you link such input with specific effects resulting from a facility's construction? We are now at the crux of the problem and there are no easy answers.

The next chapter will offer specific recommendations regarding both programs' present processes, and also attempt to grapple with the national interest criteria question。 Lastly, the idea of a regional approach to consideration of the national interest will be discussed. 
Chapter II - Footnotes

1. State of Rhode Island Coastal Management Program and Final Impact Statement, po 204.

2. Radio Campaign Advertisements, October, 1978。

3. Interview with James Beattie, Deputy Director, Coastal Resources Management Council, Department of Environmental Management.

4. State of Rhode Island Coastal Management FEIS Program, Po205.

5. State of Rhode Island Coastal Management Program FEIS, p. 301.

6. Interview with James Beattie.

7. State of Rhode Island Coastal Management Program, pp。318-321A。

8. Resource areas and their applicability to Rhode Island's Coastal Resources Management Program are too lengthy to list here and may be found on pp. 322-337 of the Rhode Island FEIS。

9. Rhode Island General Laws 46-23-4.

10. State of Rhode Island Coastal Management Program, p. 220.

11. State of Rhode Island Coastal Management Program, p. 323.

12. Boston Globe, Monday, January 8, 1979, po 18, "Governor King's Open-door Energy Policy。"

13. Massachusetts Coastal Zone Management Program, 1978, p。236.

14. Massachusetts Coastal Zone Management Program, 1978, p. 130.

15. Massachusetts Coastal Zone Management Program, p. 133.

16. Massachusetts Coastal Zone Management Program, po 136.

17. Interview with Phil Shapiro, Deputy Director of the Energy Facility Siting Council.

18. Regulations of The Energy Facility Siting Council, Dec。6, 1978, Rule 71.7.

19. Regulations of the Energy Facility Siting Council, Rule 2.1.

20. Regulations of the Energy Facility Siting Council, Rule 4.6.

21. Deputy Director, Phil Shapiro, expressed confidence in the capability of the present staff in handing compliance with the national interest provision without specific guidelines。 


\section{Chapter II - Footnotes (cont.)}

22. Energy Facility Siting Council Regulations, Rule 73.2 (3)。

23. More Information is required by petition, but is not relevant to this discussion. See part 73 of EFSC Regs。 for further information.

24. Such proposals should be forthcoming, since the injunction of the Georges Bank loan sale was lifted in 1ate March of 1979 。

25. Interview with William Clandaniel, Massachusetts Coastal Zone Management staff lawyer. 
CHAPTER III

PROGRAM RECOMMENDATIONS 
Establishing Assessment Criteria

Prior to making specific recommendations towards improving national interest processes of Massachusetts and Rhode Island, it is important to discuss how these processes could be developed into a set of criteria.

The first phase of setting criteria would have to be the establishment of a system for categorizing facilities that will be subject to a standardized assessment。 One way this could be done is to limit the national interest assessment to those facilities which require National Environmental Policy Act (NEPA) assessments。 ${ }^{1}$ NEPA assessments are carried out for projects subject to federal approval which are expected to affect significantly the quality of the human environment。 In most cases, facilities significantly affecting the quality of the human environment will produce regional, if not national effects。 By attaching state national interest assessment to the NEPA process, state approaches are equalized. Thus, one state's system (in which there is an approved coastal zone program) by reason of its lackadaisical scrutiny of facility proposals, will not entice projects away from states with tighter assessment mechanisms. Federal involvement in coastal project proposals is quite encompassing, especially with regard to energy facilities。 It would be very unlikely for a coastal proposal of national significance to escape some kind of federal review. In cases where the significance of a proposal is in question, (that is, it was subject to federal approval, but not to a NEPA assessment) a federal advisory committee could recommend the matter. Such an advisory committee could be comprised of officials from involved federal agencies, as well as state program officials。 Ideally, neighboring states would be notified of such sessions so that a better regional perspective could be engendered. If 
the situation proved especially difficult to resolve, the Secretary of Commerce's mediating powers as provided for in Sec。307(c)(3) could be utilized.

Once a method of selecting proposals is established, criteria can be applied to consider what level, if any, of national interest is involved。

1. The first task would be to determine the scope of the project. How far-ranging will its impacts be? Depending upon the facility, regional, national and international parameters could be quantified。 For instance, a regasification (LNG)plant may be proposed that has a storage capacity of 15,000 barrels。 Based on current industry practice, what are the regional, national or international implications if this facility is built? Another example could be the proposed acquisition of prime coastal land for a national park. Criteria would have to be established to see where such a park would draw from and how it would affect other parks in the region. Coupled with this impact review, would be an analysis of need. The proposal is supposed to fulfill a perceived need. Is this need projected by the applicant in keeping with the scope of the project?

2. The second phase of scrutiny would be an analysis of how well the proposed facility meets the need as established in phase 1. The criteria (possibly established by NOAA) would assess whether or not the proposed facility is the best method for achieving the desired results.

3. The last phase would allow for accommodation of federal requirements that are already established, and, in effect, recognize the national interest factors of the proposal。 For example, the Federal Energy Regulatory Commission has imposed requirements which affect the design of nuclear power plants。 ${ }^{2}$ 
Massachusetts has followed the above approach through the implementation of its energy facility siting legislation. The burden of analysis is placed on the applicant, however, and could prove to be biased in some instances. The use of NEPA assessments as an information source in undertaking the above inquiries would help to offset such imbalances. One of the main advantages of categorizing national interest facilities as those in which NEPA assessments are involved, is to avoid duplication of information generation, while at the same time taking advantage of an impartial (hopefully) investigation's materials。

Reliance on Massachusetts' energy facility siting bill for implementation of national interest assessment criteria is not prudent because the EFSC does not review non-energy facilities in which there may be a national interest. Guidelines promulgated for national interest assessment would have to be implemented by local regulatory bodies for energy facilities valued at less than $\$ 5$ million, and for other facilities in the national interest.

The above-mentioned guidelines for national interest assessment could be established by NOAA in program regulations. The present regulations list facilities in which there may be a national interest. The list includes national defense and aerospace, energy production and transmission, recreation, transportation and regional water treatment plants. 3

It is necessary for NOAA to be technical in setting up the criteria, for it must tailor its criteria to the type of resource. Potential impacts must be listed for various national interest facilities (discussed below).

Upon receiving such regulations, the states may choose to impose the burden of compliance with the criteria on the applicants. This way 
the NEPA assessment can be used as a guide, (which the state will review in light of the guidelines) and the applicant's statements of need, impact and facility design can be utilized for comparative analysis.

Guidelines issued by NOAA will be very helpful to states such as Massachusetts, where, in some instances, local regulatory bodies are making the final decision. These localities will not be burdened by trying to assess certain proposals themselves, but will have a format against which to examine proposals.

For states like Rhode Island, which have state regulatory powers over the coastal zone, the new criteria will not produce more paperwork or create a need for additional staff. The tandem approach of using the applicant's assessment based on NOAA guidelines, and NEPA assessments, will only modify the approach of the current staff in assessing national interest proposals.

The idea of using national interest assessment criteria is not new. Both Massachusetts and Rhode Island are using criteria, however, their approaches differ in degree of detail。 Rhode Island's Coastal Zone Management Council utilizes NEPA assessments when they pertain to a proposed project, but they have no guidelines on which to base their review of such NEPA assessments. Massachusetts' reviews NEPA assessments, as well as the applicant's statement of need, impact and cost, but against what criteria are they basing their review?

Michael S. Baram points out:

\footnotetext{
"The development and use of such criteria would reduce state discretion, methodological differences between states, provide more guidance for developer planning and site acquisition initiatives, and promote more objective decision-making results that are in the interest of each of the parties to coastal siting controversies." 4
} 
Baram suggests that translation of the national interest concept to criteria for decision-making does not have to be too complex a technical task. Baram limits his analysis to passive inquiries. He does not suggest what criteria should be used or how they could be obtained, nor does he describe how it could be utilized.

Contrary to Baram's opinion, for the criteria to have any substance, the promulgator of the regulation (NOAA) would have to make the criteria as technical as practically feasible. Regulations are subject to comment periods prior to becoming law, and thus private companies (which probably have the best data) will have input in the design stage. Indeed, private cooperation is essential to the accomplishment of such a task, for it is the private sector which will be the main actor. The technical criteria will have to be generated from records of private industry. What NOAA has to do is list the type of facility along with the characteristics of its capacity and function. Fundamental design standards could also be outlined. Federal program officials could use the "comment" mechanism in the regulations to alert state officials to past problems arising from certain facility deficiencies.

Basically, guidelines such as the above will give the state official a base of information for reference in his decision-making process. NEPA assessments and private industry projections could then be examined in light of common standards (NOAA regulations) produced through joint federal-private efforts.

\section{Recommendations: Massachusetts Coastal Zone Program}

Ideally, the course Massachusetts should follow to best implement the national interest provision is to pass a coastal zone management bill. 
This would provide the state primary authority over all uses significantly affecting the coast. However, Massachusetts' penchant for home rule and an ever-growing fear of government intervention makes such a proposal near fantasy. This is mentioned here to caution that certain expectations can never be fulfilled due to Massachusetts' lack of enabling legislation. For instance, the Energy Facility Siting Council will never be compelled by law to comply with MCZM policies. The Council may feel compelled due to an inter-agency agreement, but the EFSC can change its regulations and not comply with MC2M's policies if it so desires. The following proposals are directed to the program as it exists now and do not rely on legislative actions, thus allowing expeditious implementation.

To a large extent Massachusetts fulfilled the national interest clause by undertaking an inventory of the capacity of the state's coast to accommodate developments in the national interest. Massachusetts looked at the areas designated as industrial in some fifteen ports and came up with priorities for marine-dependent industrial development. An energy facility proposed for such an area will be considered marinedependent if the proposed site has been approved by the EFSC ${ }^{5}$ Again we can see a problem arising if the energy proposal is not of sufficient value to come under the jurisdiction of the EFSC. Such a facility is in 1imbo. Perhaps the EFSC could modify its regulations pertaining to oCS related development. If an OCS activity is proposed for the coast and federal approval or permits are necessary, the EFSC could assume responsibility for ensuring that adequate consideration is given to the national interest. This would take the burden off local towns, which may not have the necessary sophistication to conduct such inquiries. If 
the EFSC could not accommodate such a proposal, perhaps it could meet the localities halfway by offering technical assistance (probably through MCZM). Whether guidelines are promulgated by NOAA, EFSC or MCZM, the goal is to provide for adequate consideration of those oCS facilities presently neglected。

Massachusetts' prioritization of marine-dependent uses in specific harbors is the mechanism for ensuring that national interests can be accommodated. However, in time, it is possible that other uses may encroach on these designated areas due to lack of proposals in the national interest. It is recommended that MCZMP conduct a five-year re-assessment of all priority areas to monitor such growth.

New ocS related development pressure seems to be growing in Massachusetts. The Georges Bank injunction has been lifted and lease sales are scheduled for October, 1979. Also there has recently been talk of a possible oil refinery proposal for Fall River. Certain areas may have been designated high priority several years ago, but such designation does not preclude other development. When two or more proposals are proffered for the same site, the marine-dependent proposal will probably win. Massachusetts has an expanding fishing industry, a marine-dependent use, which may result in more "Priority" areas being utilized. Ocs related activities that are slow in coming may not be provided for. Due to many other marine-dependent uses in Massachusetts and un-monitored land use in the prioritized ports, adequate consideration of the national interest is suffering。

The Energy Facility Siting Council should tighten its procedures for complying with the national interest clause. Specifically, the EFSC should lay down guidelines for staff members to follow in soliciting 
comments from interested federal agencies. The EFSC's reliance on industry's generation of such agencies is not adequate. Presently, staff members know what agencies should be contacted through experience. However, as there is a turnover in staff, such competence may not remain. A list of each type of energy facility, along with the relevant federal agencies should be compiled. The incorporation of these guidelines into the EFSC's process will reduce the level of discretionary authority exercised, and assure equal treatment of project proposals。 The EFSC's public hearing process could be further improved by proper recording of testimony at local public hearings. Such testimony should be forwarded to the Council members to aid in their consideration of the project's national interest merits. Currently, a local resident must go to Boston for an adjudicatory hearing. Many residents may be unable to get to Boston for such hearings, or the trip may discourage them from voicing their opinions. The EFSC should establish hearing procedures which are as accessible to the public as possible。 Local insights can be very helpful to decision-makers when trying to balance the national interests of a particular project. Massachusetts' fulfillment of the regional benefit clause is very good for some facilities, but fair for others. The only case where the EFSC can not supersede local regulations involves the siting of oil facilities other than pipelines. If a local zoning classification prohibits oil facilities and is recorded prior to an oil company's notice of intention to construct, the EFSC override is rendered useless. There is nothing the EFSC can do to tighten this procedure, short of seeking amendments through the Legislature. What the EFSC could do is to be aware of localities which try to pass anti-oil ordinances if and when 
a significant find is made on Georges Bank. The EFSC has no power to stop a locality from doing this, and it probably shouldn't. However, if the EFSC is aware of such developments, it can present its case to municipal authorities, stressing the national purpose involved.

Tables 1 and 2 depict both states' compliance aspects with Section 306(c)(8) and 306(e)(2). Basically, the main flaw in Massachusetts' compliance with these provisions is the EFSC's option of abandoning any kind of cooperation with MCZM。 Since the EFSC is the implementing arm for MCZM's compliance with Sec's. 306(c)(8) and (e)(2), this is a serious flaw。 The other major drawback to Massachusetts' adequate consideration of the national interest is the lack of any criteria for decision-makers to follow. If there are no criteria for decisions, there are no decision points. The whole crucial phase of decisionmaking is very ambiguous.

The recommendations made above will, hopefully, work towards mitigating some of the potentially adverse decisions which could thwart the intent of the Act as expressed in the Congressional findings, Sec. 302(a), and implemented by Sections $306(c)(8)$ and $306(e)(2)$. C. Recommendations: Rhode Island Coastal Resources Management Program Effective implementation of the national interest provision in Rhode Island is dependent upon some form of energy facility siting law being passed. Presently, there is energy facility siting council legislation pending. The bill, introduced in 1978 by The Garrahy Administration, has been labeled unwieldy and unnecessary by its critics. Others are pushing for quick adoption so that the state can prepare itself for major energy facility location ramifications. The proposed Charlestown Nuclear Plant is thought to be a major catalyst for the bill's emergence. 
Regs。 pertain-

ing to $306(c)(8)$

$923.52(b)(1)$

$923.52(b)(2)$

$923.52(b)(3)$

$923.52(c)(1)$

$923.52(c)(2)$

\section{MASSACHUSETTS}

- NERBC provided MCZMP with 1ist of 35 federal agencies to solicit views from

- Mission statements from federa1 agencies were not made explicit

- Policy statements, federal laws, special reports, public hearings also utilized

- National interest five-step consideration procedure outlined in policy 8 of MA FEIS

- APR/ACEC areas will receive prime consideration for coastal resource construction

- EFSC implements this section of MCZMP

- EFSC appeals process addresses conflicts in most cases. EFSC has legal power to override local decisions (with some exceptions)

- Five step procedures outlined in Policy 8 provides for continued consideration of the national interest in only those activities coming under EFSC's jurisdiction

- Administrative procedures and decision points for making de cisions in the national interest are not detailed

Not applicable

- Massachusetts energy facility siting law which created the energy facility council meets this requirement
RHODE ISLAND

- HEW series of 4 state-federal workshops

- State-federal coordinator temporarily appointed

- Enlisted aid of NERBC

- Created federal advisory committee

- R。I. FEIS contains summary of federal agency mission description/policy statements

- R。I。FEIS explicitly lists federal views to be solicited for various facilities

- National interests listed in facilities is linked directly to program elements

- Federal advisory committee shall function as the principle mechanism for conflict resolution no legal power

- Continued consideration of identified national interests is provided for in the program for each facility where there is national interest.

- Administrative procedures and decision points for making decisions in the national interest are not detailed

Not applicable

Rhode Island meets this requirement by outlining study to be undertaken。 Elements are detailed in $R_{0} I$ 。 FEIS section $610.1-2$

"Planning Policies" 
*Regs. pertaining to $306(e)(2)$

$923.13(a)(1)$

$923.13(a)(2)$

\section{MASSACHUSETTS}

Uses "national interest" and "regional benefit" synonomously

- The only case where the EFSC cannot supercede local regulations involves the siting of oil facilities other than pipelines. If a local zoning by-law prohibiting oil facilities has been placed into effect prior to a filing by an oil co. of a notice of intention to construct. The EFSC cannot override the ordinance.
RHODE ISLAND

Uses "national interest" and "regional benefit" synonomously

- Federal Advisory Council functions as principle mechanism for conflict resolution.

- FAC has no legal power to override any local decisions.

- R.I.'s Act creating the Coastal Resources Management Council (1971) provides the power of binding arbitration to council in matters of dispute involving both the resources of the states coastal region and the interests of two or more municipalities or state agencies. 
Under the proposed bill, a 17 member council will be formed with final and possibly sole, state licensing authority for all types of energy facilities. High voltage lines would be covered under the bill, so it appears that there isn't a ceiling placed on projects eligible for the council's reviews, such as Massachusetts $\$ 5$ million ceiling. 6 Existing state 1 aw provides that the Coastal Resources Management Council (CRMC) regulate and authorize any project proposal for coastal areas. The CRMC has recently accepted regulations relating to energy facilities. The Department of Environmental Management and the State Public Utilities Commission have approval authority over certain aspects of energy facilities. It does not seem necessary to create another regulatory authority for energy facilities in $R_{0} I$. The state should utilize the 17 member Coastal Resources Management Council for energy regulation. New regulations have been adopted by the Council pertaining to energy facilities. New staff will probably be needed for implementation, especially with the recent mounting of energy activity in Rhode Island (OCS related, and nuclear power activity)。 Rhode Island doesn't need an independent Energy Facility Siting Council similar to Massachusetts. Massachusetts had to create an energy facility siting council because it had no alternative. It does not have a single regulatory body overseeing the coast as does Rhode Island.

The CRMC could effectively handle energy facility proposals anywhere in the state due to its wide discretionary authority。 The CRMC has authority over any project proposal in the state if it is deemed to have an effect on the coast. Most energy facilities are located on the coast, but if there are exceptions, the CRMC could still legally regulate the activity. 
The proposed siting legislation is on point in its creation of an energy facility planning process. The bill proposes that the Statewide Planning Program be empowered to undertake evaluations of 1 ong and short term energy needs, including "optimum" use of alternative sources of energy. 7 Possibly Statewide Planning's staff could serve as the CRMC's staff in its energy facility evaluations. In this way, no new staff would be needed for implementation. Such a networking approach to energy facility planning could prove to be, not only the best approach fiscally, but also the most comprehensive. Regardless of staffing details, Rhode Island needs a tighter energy facility regulatory system. Demand forecasts, supply plans, financial information, and market area studies are all valuable data that must be generated in a systematic fashion from initiators of development. Amendments to the Act which created the Coastal Resources Management Council should be made thus empowering it as the authority over energy facility development. The new amendments could set the foundation for the promulgation of regulations implementing an energy facility planning process. Generation of pertinent information with regard to energy facilities will aid the national interest assessment by providing decision-makers with a full range of data allowing for proper weighing of the varying interests.*

The above recomendation could be buttressed if the Federal office of Coastal Zone Management promulgated the decision criteria guidelines mentioned in the beginning of this chapter. Rhode Island should act now, however, and attempt to set up its own criteria for its decision-makers. *It would seem likely that an "Energy Advisory Panel" with expertise in all energy fields would have to be created to assist the CRMC in its disposition of such cases. The Coastal Energy Comnittee now situated in the Governor's Energy office could function in this capacity. The CEC presently prioritizes projects within the state eligible for Coastal Energy Impact Program Funds. This 7 member committee consists of private business and state representatives (officials). 
Decreasing the amount of discretionary authority which now exists and providing equitable treatment to all facilities is the primary objective. Rhode Island also needs a stronger conflict resolution mechanism to comply properly with the regional benefit clause. Under existing procedures, the Federal Advisory Committee (FAC) functions as the principle mechanism for conflict resolution and direct federal agency council coordination and consultation during implementation of the Coastal Resources Management Program. This committee is to meet at a minimum of every three months. The FAC has not yet met, due to the lack of proposals where regional benefit may be involved.

The FAC does not have the legal authority to override local decisions if such decisions serve to restrict unreasonably or exclude uses of regional benefit. The advisory committee does just that--advise. A veto power similar to Massachusetts' EFSC appeals process would provide a good measure of control on the arbitrariness of a local town's decision that has regional implications. This veto power could be provided for in the above-mentioned amendments to Rhode Island's Coastal Resources Management Act. It is extremely important that the regional benefit clause be taken seriously. Improper fulfillment of this provision can serve to emasculate the effect of the national interest provision as intenced by Congress.

Althoigh there are not many major weaknesses in the programs of Massachusetts and Rhode Island, the $\mathrm{flaws}$ that do exist are impediments to the operation of programs that thoroughly consider the nationai interests in the siting of energy facilities.

OCS related onshore development looms large over the Rhode Island and Massachusetts coasts since the lifting of the injunction on Georges 
Bank lease sales. Both Massachusetts and Rhode Island should move quickly to install mechanisms in their respective programs. This will insure that prospective energy development on the coast will be carried out in keeping with the intent of Congress to provide for the beneficial use, protection, and development of the coastal zone. 8

Area for Further Study: A Regional Approach to National Interest Facility $\underline{\text { Siting }}$

The concept of a regional approach to coastal zone management has long been thought of as a "nice idea" but no one was willing to take a hard look at its feasibility. Possibly one of the reasons for such indifference is that Sec. 309 of the Act, which provides for interstate planning grants, has never been funded. The fiscal year 1979 budget, however, has changed that by appropriating in the area of $\$ 400,000$ to finance Sec. 309.8 These will be 90 percent matching grants, and already there is a proposal submitted by Professor Gaither working from the University of Delaware. 9

The Office of Coastal Zone Management is pleased with the new interest in regionalization, and has identified tanker traffic and energy facility siting as high priority multiple-state solution areas. ${ }^{10}$ The University of Delaware regional study program has set up eight task groups covering:

1. dredged material disposal and sediment transport

2. assimilative capacity of the Atlantic offshore area for receiving waste

3. wave data acquistion and use

4. management of living resources

5. modeling physical processes 
6. offshore zoning

7. soil strength and stability

8. interaction of structures, equipment and the marine environment

Energy facility siting, not covered by Professor Gaither (probably due to its recent emergence as a priority issue) should be added to such regionalization efforts.

A regional approach in evaluating adequate consideration of the national interest provision makes a lot of sense. Presently, each state considers the various national interests in its program as confined by its political boundaries. These national interests, as identified by a single state, cannot be considered in their full context unless the state looks outside its borders. This is due to the fact that for a facility (national park, power plant, airport, etc.) to be in the national interest, it is affected by parties of a regional nature.

The method of categorizing a region has been an item for debate among geographers for many decades. Some espouse the use of vegetation as the main criterion, others geologic formations. Such basic geophysical characteristics not only link areas into regions, but also affect the course of development within the region through time. New England is classified as a region by many geographers due to similarities in vegetation and geology. The glacial periods acted to carve out such distinctions. As a result of its glacial history, New England is blessed with great diversity in its physical composition. An abundance of beaches, lakes, rivers, bays and natural relief has promoted various types of development serving different interests.

The case could be made that New England should be looked at as one 
area in its fulfillment of the national seashore that is used by people from all over the country. Logan Airport is a major facility serving the entire northeast region. The Massachusetts'fishing industry also has national impacts. Rhode Island has Narragansett Bay, which affords great development sites, as attested by Quonset/Davisville, the current support base for OCS drilling in the Baltimore Canyon. Rhode Island also has beautiful beaches and a growing fishing industry, both of which impact on a national scale.

What is advocated here is a more comprehensive approach to national interest consideration. Should Massachusetts' role as a tourist have been impaired by the location of tank farms, which will only affect the energy supply of the Northeast? Rhode Island has made OCS related onshore development part of its economic recovery plan. Should Massachusetts be forced to locate a national interest facility it does not want, when Rhode Island desires to have the project? All that separates the two states is a political boundary. We should not allow such artificial obstructions to impede the important task of adequately considering the national interest for the region.

Now that Sec。 309 funds are available, it is possible for states like Massachusetts and Rhode Island to enter compacts。 Interstate energy plans would be one mechanism that would greatly enhance the rationality of assessing states' fulfillment of the national interest. On major projects the states could review each other's energy and land-use plans to achieve a maximum utilization of national interest facilities。

A specific area of further study could be to analyze just how states such as Rhode Island and Massachusetts could complement each other in their resource development strategies. Detailed studies would be needed 
on the market impacts of present facilities, as well as modeling techniques for assessing cause and effect relationships. One of the major tasks would be to devise an organizational structure which facilitates an exchange of information that is directly linked to the implementation of strategies.

The recommendations 1 isted here should enable Massachusetts and Rhode Island to produce timely, pertinent information, which will work toward meeting the national interest goal in coastal zone management。 A regional approach to national interest facility siting can only be accomplished when the states have filled the gaps in their respective programs. 


\section{Footnotes}

1. Michael S。Baram, Environmental Law and the Siting of Facilities: Issues in Land Use and Coastal Zone Management, p. 151.

2. Michael S。 Baram, po 150。 Here Baram proposes an outline for national interest assessment, on which $I$ have elaborated in the above three (3) phases.

3. Federal Register, Wednesday, March 1, 1979 Part II Department of Commerce National Oceanic and Atmospheric Administration, State Coastal Management Programs.

4. Michael S。 Baram, po 150。

5. Massachusetts Coastal Zone Management Program, p。 55.

6. The Narragansett Times "Thursday, January 11, 1979, p.4.

7. The Narragansett Times, Thursday, January 11, 1979, po4 "Okay as is。"

8. Coastal Zone Management Act of 1972, Section 302(a).

9. John R. Botzum and Rose Jacobius, Editors, Coastal Zone Management, Volume 9, no. 31, August 9, 1978, p.1.

10. John R。 Botzum and Rose Jacobius, Coastal Zone Management, p.3. 
$-73-$

APPENDIX

FEDERAL REGULATIONS

FOR THE NATIONAL INTEREST AND

REGIONAL BENEFIT PROVISIONS

REQUIREMENTS 
923.13 Uses of regional benefit.

(a) Requirement. In order to meet the requirements of subsection $306(e)(2)$ of the Act, State's must:

(1) Identify what constitute uses of regional benefit; and

(2) Identify methods that will assure that local land and water use regulations do not unreasonably restrict or exclude land and water uses of regional benefit.

\subsection{Consideration of national interests.}

(a) General. The primary purpose in requiring, pursuant to subsection $306(c)(8)$ of the Act, adequate consideration of national interests involved in the planning for and siting of facilities (which are necessary to meet other than local requirements) is to assure that such facilities are considered in (1) the development of the State's management program, (2) the review and approval of the program by the Assistant Administrator, and (3) the implementation of the program as such facilities are proposed. One need not conclude from this that any and all such facilities proposed for the coastal zone need be sited therein. The Act presumes a balancing of national interests in such facilities as defense installations, energy production and distribution facilities and highways with Federal, State and local concerns involving adverse economic, social or environmental impacts.

(b) Requirement. In order to meet the requirements of subsection $306(\mathrm{c})(8)$ of the Act, States must:

(1) Describe which national interests in the planning for and siting of facilities (which are necessary to meet requirements that are more than local in nature) were considered during program development and the sources relied upon for such consideration;

(2) Indicate how and where the consideration of these national interests is reflected in the substance of the management program including, where appropriate, indication of when and where national interests in identified facilities may compete or conflict with other national interests in coastal resource conservation. In cases of such conflict, the program shall indicate how the conflict has been or can be weighed and resolved;

(3) Describe a process for continued consideration of identified national interests (in facilities which are necessary to meet requirements that are more than local in nature) during program implementation, including a clear and detailed description of the administrative procedures and decision points where such interests can be considered.

(c) Requirement. With specific reference to meeting the requirement for adequate consideration of the national interest in the planning for and siting of energy facilities in, or which significantly affect, a State's coastal zone, States shall, in addition to the requirements of (b) above: 
(1) Consider any applicable interstate energy plan or program developed pursuant to section 309 of the Act; and

(2) Meet the requirements for an energy facility planning process pursuant to the requirements of 923.14 except that:

(i) States with a management program approved prior to October 1 , 1978, that do not meet the requirements of subsection $305(\mathrm{~b})(8)$ of the Act shall:

(A) Describe existing or developing management program standards or policies as these apply to energy facility planning and siting; and

(B) Describe briefly the status of the planning process required pursuant to subsection $305(\mathrm{~b})(8)$ of the Act。 


\section{$-76-$}

PERSONAL INTERVIEWS

Robert W. Knecht, Associate Administrator, National Oceanic and Atmospheric Administration, Office of Coastal Zone Management, Washington, D.C.

Edward Lindeloff, State Programs Office, Office of Coastal Zone Management, Washington, D.C.

Phillip Shapiro, Deputy Director, Massachusetts Energy Facility Siting Council

William Clandaniel, Attorney, Massachusetts Coastal Zone Management Program

James Beattie, Deputy Director, Rhode Island Coastal Resources Management Council 
Bibliography

1. Baram, Michael So Environmental Law and the Siting of Facilities: Issues in Land Use and Coastal Zone Management Cambridge,: Ballanger $\overline{\text { Publishing Col, } 1976 .}$

2. The Boston Globe

3. Botzum, John $\mathbf{R}_{0}$, Jacobius, Rose, Editors, Coastal Zone Management Volume 9, No。31, August 9, 1978. Nautilus, Washington, D。C。

4. Frankel, Joseph, National Interest. London: Pall Mall Press, 1970.

5. Gray, Oscar S。 Environmental Law: Cases and Materials, Bureau of Nat1. Affairs, Inc., Washo, D. C. 1973.

6. Hershmare, Marc Jo, Feldman, James H。 Coastal Management: Readings and Notes, Institute for Marine Studies Coastal Resources Program University of Washington, Seattle, January, 1979.

7. Langlois, Richard, Energy Facility Siting and the National Interest (paper) Center for Technology and Environmental Resource Policy, Stanford University。

8. Mandelker, Daniel R., Environmental and Land Controls Legislation, Indianapolis: Bobbs-Merrill Co., Inc。1976。

9. Narragansett Times

10.

11. Roughgarden, Jeffrey Do, Energy Facility Siting and the National Interest, Volume II "Conceptual Foundations," Center for Technology and Resource Policy, Stanford University. (no date given)

12. Coastal Zone Management Act of 1972 (P.L. 92-583) and the 1976 Amendments ( $P L$ 。94-370)。

13. Legislative History of the Coastal Zone Management Act of 1972 , as Amended in 1974 and 1976 with a Section by Section Index, Prepared by the Library of Congress, Congressional Research Service, Washington, D。C., July 26, 1976 。

14. Letter to Ms . Carol Sonheimer, State Programs Office, Office of Coastal Zone Management, National Oceanic and Atmospheric Administration, U.S. Dept。 of Commerce, from C。T. Sawyer, V。P., American Petroleum Institute, Re: Interim Final Regulations, 15CFR part 923, April 19, 1978。

15. Letter to $M_{0}$ Carol Sonheimer from Edison Electric Institute Re: Interim Final Regulations 15CFR part 923. April 19, 1978. 
16. Land Use and Environmental Law Review, 1978, "Toward Better Use of Coastal Resources: Coordinated State and Federal Planning under the CZMA.

17. Massachusetts Coastal Zone Management Program and Final Environmental Impact Statement, 1978.

18. Massachusetts Energy Facility Siting Council, Regulations, December 6, 1978。

19. Rhode Island General Law 46-23-1, 1971 - An Act creating a Coastal Resources Management Council. 